\title{
Cladistic analysis of olfactory and vomeronasal systems
}

\section{Isabel Ubeda-Bañon', Palma Pro-Sistiaga'2 , Alicia Mohedano-Moriano³, Daniel Saiz-Sanchez', Carlos de la Rosa-Prieto', Nicolás Gutierrez-Castellanos ${ }^{4}$, Enrique Lanuza ${ }^{4}$, Fernando Martinez-Garcia ${ }^{4}$ and Alino Martinez-Marcos ${ }^{1 *}$}

\author{
Laboratorio de Neuroplasticidad y Neurodegeneración, Departamento de Ciencias Médicas, Centro Regional de Investigaciones Biomédicas, Facultad de Medicina de \\ Ciudad Real, Universidad de Castilla-la Mancha, Ciudad Real, Spain \\ 2 GIP Cyceron, Campus Jules Horowiz, Caen, France \\ ${ }^{3}$ Laboratorio de Neuroanatomía Humana, Departamento de Ciencias Médicas, Centro Regional de Investigaciones Biomédicas, Facultad de Medicina de Albacete, \\ Universidad de Castilla-La Mancha, Albacete, Spain \\ ${ }_{4}^{4}$ Laboratori de Neuroanatomia Funcional i Comparada, Departaments de Biologia Cel/.lular i Biologia Funcional, Facultat de Ciències Biològiques, Universitat de Valencia, \\ València, Spain
}

\section{Edited by:}

Agustín González, Universida

Complutense de Madrid, Spain

\section{Reviewed by:}

Jorge A. Larriva-Sahd, Universidad

Nacional Autónoma de México, Mexico

Carla Mucignat, Università degli Studi

di Padova, Italy

\section{*Correspondence:}

Alino Martinez-Marcos, Facultad de

Medicina de Ciudad Real, Universidad

de Castilla-La Mancha, Avda. de

Moledores S/N, 13071 Ciudad Real,

Spain.

e-mail: alino.martinez@uclm.es
Most tetrapods possess two nasal organs for detecting chemicals in their environment, which are the sensory detectors of the olfactory and vomeronasal systems. The seventies' view that the olfactory system was only devoted to sense volatiles, whereas the vomeronasal system was exclusively specialized for pheromone detection was challenged by accumulating data showing deep anatomical and functional interrelationships between both systems. In addition, the assumption that the vomeronasal system appeared as an adaptation to terrestrial life is being questioned as well. The aim of the present work is to use a comparative strategy to gain insight in our understanding of the evolution of chemical "cortex." We have analyzed the organization of the olfactory and vomeronasal cortices of reptiles, marsupials, and placental mammals and we have compared our findings with data from other taxa in order to better understand the evolutionary history of the nasal sensory systems in vertebrates. The olfactory and vomeronsasal cortices have been re-investigated in garter snakes (Thamnophis sirtalis), short-tailed opossums (Monodelphis domestica), and rats (Rattus norvegicus) by tracing the efferents of the main and accessory olfactory bulbs using injections of neuroanatomical anterograde tracers (dextranamines). In snakes, the medial olfactory tract is quite evident, whereas the main vomeronasalrecipient structure, the nucleus sphaericus is a folded cortical-like structure, located at the caudal edge of the amygdala. In marsupials, which are acallosal mammals, the rhinal fissure is relatively dorsal and the olfactory and vomeronasal cortices relatively expanded. Placental mammals, like marsupials, show partially overlapping olfactory and vomeronasal projections in the rostral basal telencephalon. These data raise the interesting question of how the telencephalon has been re-organized in different groups according to the biological relevance of chemical senses.

Keywords: amygdala, cortex, evolution, olfaction, olfactory bulb, vomeronasal

\section{INTRODUCTION}

Odor perception is initiated by interactions between odorants (sensu lato) and a diverse repertoire of receptors in sensory neurons (Ache and Young, 2005; Bargmann, 2006; Kaupp, 2010). Classical

Abbreviations: ac, anterior commissure; ACo, anterior cortical amygdaloid area; ADVR, anterior dorsal ventricular ridge; $\mathrm{AOB}$, accessory olfactory bulb; aot: accessory olfactory tract; BAOT, bed nucleus accessory olfactory tract; BNST, bed nucleus stria terminalis; CA, cornu ammonis areas; CA1-3, fields CA1-3 of cornu ammonis; CxA, cortex-amygdala-transition zone; DC, dorsal cortex; DG, dentate gyrus; DLA, dorsolateral amygdaloid nucleus; dlo, dorsal lateral olfactory tract; dmRF, dorsomedial retrobulbar formation; GL, glomerular layer; GrL, granular cell layer; IC, islands of calleja; iot, intermediate olfactory tract; LC, lateral cortex; LE, lateral entorhinal cortex; lfb, lateral forebrain bundle; lot, lateral olfactory tract; MC, medial cortex; Me, median eminence; MeAD, medial amygdaloid nucleus, anterodorsal; MeAV, medial amygdaloid nucleus, anteroventral part; meot, medial olfactory tract; $\mathrm{MePD}$, medial amygdaloid nucleus, posterodorsal part; MePV, medial amygdaloid nucleus, posteroventral part; NS, nucleus sphaericus; $\mathrm{MOB}$, main olfactory bulb; mot, medial olfactory tract; OG, olfactory gray; OT, olfactory tubercle; ot, optic tract; PDVR, posterior dorsal ventricular ridge; Pir, piriform cortex; PMCo, posteromedial cortical amygdaloid area; PMLo, posterolateral cortical amygdaloid area; S, septum; sm, stria medullaris; ST, striatum; Tu, olfactory tubercle; TT, taenia tecta; VPA, ventral posterior amygdala. neuroanatomical studies have investigated the olfactory system in a number of species of different taxa including fishes (s.l.; Hara, 1975; Laberge and Hara, 2001; Hamdani el and Doving, 2007), amphibians (Duchamp-Viret and Duchamp, 1997), reptiles (Lohman and Smeets, 1993), birds (Rieke and Wenzel, 1978), and mammals (Shepherd, 1972). These reports have allowed the characterization of the olfactory "cortex" in most vertebrates. Also, neuroanatomical investigations lead to the identification of the vomeronasal "cortex" in mammals (Winans and Scalia, 1970; Raisman, 1972; Scalia and Winans, 1975). The main conclusions of all these reports were that chemosensory cortex lacks odotopy and that olfactory and vomeronasal projections reached adjacent, non-overlapping zones in the telencephalon.

During the last two decades, the cloning of different olfactory (Buck and Axel, 1991; Liberles and Buck, 2006) and vomeronasal (Dulac and Axel, 1995; Bargmann, 1997, 1999; Herrada and Dulac, 1997; Matsunami and Buck, 1997; Ryba and Tirindelli, 1997) receptors has allowed considerable progress in tracing olfactory and vomeronasal perception from receptors to the activity of sensory 
neurons to higher processing centers and, ultimately, to behavior (Buck, 1995, 1996, 2000, 2004; Mombaerts, 1996, 1999a,b, 2004; Mombaerts et al., 1996; Dulac, 1997, 2000; Dulac and Torello, 2003; Brennan and Keverne, 2004; Brennan and Zufall, 2006; Dulac and Wagner, 2006; Cleland, 2010). Interactions and synergic activation of both systems, however, occurs in early stages of neural processing (Xu et al., 2005; Slotnick et al., 2010).

The genetic and molecular approaches to the study of the organization of chemosensory systems have allowed a step forward to understand the organization of chemosensory systems. Genetic tracing of given receptors constitutes a valuable tool for this aim. The present review tries to provide a global panorama on the organization and evolution of olfactory and vomeronasal cortices with emphasis on recent advances including tract-tracing as well as genetic and molecular approaches. Own data of reptiles, marsupials and placental mammals are re-analyzed in the context of current knowledge of main taxa of vertebrates.

\section{TAXONOMIC OVERVIEW OF VERTEBRATES}

Although a complete description of the taxonomic classification of vertebrates is out of the scope of the present manuscript, a brief outline of the main vertebrate taxa will be useful not only for the comparative strategy herein used but also to help non-familiarized readers to understand such organization. For the sake of clarity, the main taxonomic categories have been maintained but simplified. This hierarchical organization is explained below and has been adapted from Hickman and collaborators (Hickman et al., 2007).

The Phylum Chordata is defined by the presence of notochord. In its basic plan these animals are bilateral, coelomed, metameric, and cephalized. This Phylum includes the Groups Prochordata (with the SubphylaUrochordata-tunicates-andCephalochordata-amphioxus) and Craniata (with the Subphylum Vertebrata). Within Subphylum Vertebrata are included the Superclasses Agnata (jawless, with the Classes Mixinoidea-mixins - and Cephalaspidomorpha-lampreys) and Gnathostomata (jawed, with the Classes Chondrichthyes - cartilaginous fishes - Osteichthyes -bony fishes - Amphibia, Reptilia, Aves, and Mammalia. The Class Mammalia includes the Subclasses Prototheria -monotremas - and Theria. The Subclasse Theria comprises the Infraclasses Metatheria - marsupials - and Eutheria with several Orders in which highlights the Order Primate. Finally, within the Order Primate consist of the Superfamilies Platyrrhini-new world monkeys - Catarrhini - old world monkeys - and Hominidae in which we are included.

\section{AGNATA, JAWLESS}

Among superclass Agnata most data in the literature regarding the organization of the olfactory system have been obtained in lampreys. Reports on the lamprey olfactory system has been devoted to the organization of the olfactory mucosa (Thornhill, 1967; Suzuki, 1984; VanDenbossche et al., 1995; Laframboise et al., 2007), olfactory bulbs (Iwahori et al., 1987a; Melendez-Ferro et al., 2001; Pombal et al., 2002), and telencephalon (Chiba, 1999; Pombal et al., 2002; Perez-Costas et al., 2004). The projections from the olfactory bulb identified medial and lateral olfactory tracts (LOT) reaching dorsal, lateral, and probably medial pallium as well as the posterior diencephalon as well as reciprocal, centrifugal projections to the bulb (Northcutt and Puzdrowski, 1988; Polenova and Vesselkin,
1993). On the other hand, the origin of the vomeronasal system is uncertain. It was classically considered that the vomeronasal system was developed by tetrapods and it was hypothesized to be an adaptation to terrestrial life (Eisthen, 1997). It has been demonstrated that lampreys detect pheromones (Fine and Sorensen, 2008) and display some genetic components of the vomeronasal system (Grus and Zhang, 2009). Also, an accessory olfactory organ has been shown to send separated projections from those of the main olfactory epithelium to the medial portion of the bulb (Ren et al., 2009). No further differential projections from this medial portion of the bulb to the pallium have been investigated. Therefore, data in the literature suggests that primordial elements of the vomeronasal system could be already present in jawless vertebrates.

\section{CHONDRICHTHYES, CARTILAGINOUS FISHES}

The olfactory system, including the olfactory epithelium (Ferrando et al., 2006, 2007, 2009; Zaccone et al., 2010) and the secondary connections from the olfactory bulbs have been investigated in sharks and rays (Smeets, 1983). Secondary olfactory centers have been neurochemically characterized as well (Yuen et al., 2005). Like lampreys, cartilaginous fishes display some genetic components of the vomeronasal system (Grus and Zhang, 2009). The distribution of $G$ proteins suggests incipient segregated primary olfactory projections (Ferrando et al., 2009).

\section{OSTEICHTHYES, BONY FISHES}

The teleosts olfactory system has been investigated including the olfactory organs (Wilson and Westerman, 1967; Westerman and Wilson, 1968; Goel, 1978; Jain and Sahai, 1991), olfactory bulbs (Kosaka and Hama, 1982; Alonso et al., 1989; Satou, 1990), and olfactory-recipient areas (Singru et al., 2003; Gaikwad et al., 2004). The olfactory projections from the olfactory bulbs have been investigated in teleosts, with studies including early anatomical reports (Scalia and Ebbesson, 1971; Finger, 1975; Murakami et al., 1983). These projections have been re-investigated using modern genetic approaches (Miyasaka et al., 2009). In teleost fishes, whose telencephalon is everted (Butler, 2000; Mueller and Wullimann, 2009), the secondary olfactory projections terminate in non-cortical areas of the telencephalon (Folgueira et al., 2004). Interestingly, three pathways from different receptors to different areas in the olfactory bulb and to different areas in the telencephalon have been characterized in teleost fishes devoted to detect social cues, sex pheromones, and food odors (Hamdani el and Doving, 2007). In fact, not only vomeronasal receptors have been described in several species (Pfister et al., 2007), but, in lungfishes, it has been recently reported a complete vomeronasal system (Gonzalez et al., 2010).

\section{AMPHIBIA}

Studies on the amphibian olfactory system include reports focused in the olfactory epithelium (Getchell et al., 1989; Daston et al., 1990; Crowe and Pixley, 1992; Krishna et al., 1992), olfactory bulb (Scalia et al., 1991b), and olfactory-recipient areas (Gonzalez and Smeets, 1991; Petko and Santa, 1992; Marin et al., 1997; Brox et al., 2004). The differential projections from the olfactory and vomeronasal epithelia to the main and accessory olfactory bulbs (AOB) were reported in several species (Taniguchi et al., 2008). The amphibian AOB has been investigated as well (Saito et al., 2006). 
Secondary olfactory projections were early addressed in amphibians (Northcutt and Royce, 1975). The differential projections from the main and AOBs were reported later on reaching cortical and non-cortical areas of the telencephalon, respectively (Scalia, 1972; Scalia et al., 1991a). The vomeronasal system was fully described more recently including not only hodology, but neurochemical and gene expression characterization (Moreno et al., 2005; Moreno and Gonzalez, 2007). Interestingly, heterogeneous expression of $G$ proteins have been reported in the amphibian olfactory and vomeronasal epithelia (Jungblut et al., 2009). Vomeronasal receptor genes have been reported to be also expressed in the main olfactory epithelium indicating that some pheromone-like triggered behaviors (Woodley, 2010) are mediated via the olfactory system in some amphibians species (Date-Ito et al., 2008).

\section{REPTILIA}

Research on the reptilian olfactory system includes reports focused to olfactory receptors (Steiger et al., 2009), olfactory and vomeronasal epithelia (Wang and Halpern, 1982a,b, 1988; Iwahori et al., 1987b; Kondoh et al., 2010), olfactory bulbs (Iwahori et al., 1989a,b; Kosaka et al., 1991), and olfactory-recipient telencephalic areas (Smeets et al., 1986, 1987; Smeets, 1988; Smeets and Steinbusch, 1990). In reptiles, the main and AOBs projections were investigated in a number of species, mainly lizards and snakes (Gamble, 1952, 1956; Halpern, 1976; Lohman et al., 1988; Martinez-Garcia et al., 1991; Lanuza and Halpern, 1998). These projections have also reviewed (Lohman and Smeets, 1993). Both projections are reciprocated by backwards centrifugal projections (Martinez-Garcia et al., 1991; Lanuza and Halpern, 1998). The projections from the main olfactory bulb (MOB) are characterized by lateral, intermediate, and medial olfactory tracts (MOT; Figure 1). The lateral projection is the most robust projection and ends in the superficial layer of the reptilian lateral cortex (Figure 1). The projection from the AOB courses through the accessory olfactory tract (AOT) to reach the vomeronasal amygdala, within the reptilian amygdaloid complex (Martinez-Garcia et al., 1993; Martinez-Marcos et al., 1999). The vomeronasal amygdala is mainly composed by the nucleus sphericus, a folded, cortical-like structure. The vomeronasal projection ends in the inner layer of this nucleus (Figure 2). The projections from the main and AOBs in reptiles are summarized in Figure 3.

\section{AVES}

The avian olfactory system has been investigated from olfactory receptors (Nef et al., 1996) to olfactory epithelium (Slaby, 1987), olfactory bulb (Cobb, 1960; Ioale and Papi, 1989), and olfactory-recipient areas (Dietl and Palacios, 1988). The olfactory bulb projections in Aves were studied with Fink-Heimer technique demonstrating a bilateral non-symmetrical terminal field (Rieke and Wenzel, 1978). Using autoradiographic techniques, the avian olfactory bulb projections were compared to those of turtles. The main conclusions were that both projections were similar regarding "olfactory cortex," but they do differ significantly regarding projections to the amgydaloid region, being this latter reduced to the nucleus taeniae in the case of birds (Reiner and Karten, 1985). These projections have been characterized using neural tracers as well (Ebinger et al., 1992). Avian olfaction have been largely related to navigation (Gagliardo et al., 2009). In fact, the olfactory forebrain is quite specialized in migratory birds like anseriforms (Ebinger et al., 1992). New techniques based on the combinatorial expression patterns of neural markers and developmental regulatory genes have allowed to identify zones in the olfatorecipient area of the ventral pallium comparable to piriform, entorhinal, amygdalopiriform, and amygdaloid cortices of mammals (Martinez-Garcia et al., 2002; Abellan et al., 2009). Finally, analysis of olfactory receptor gene repertoires show that in all species studied, amplified olfactory receptor sequences were predicted to be from potentially functional genes thus suggesting that olfaction in birds may be a more important sense than generally believed (Steiger et al., 2008; Balthazart and Taziaux, 2009). The issue of avian pheromones is still far from been resolved (Caro and Balthazart, 2010).

\section{METATHERIA, MARSUPIALS}

Marsupials lack corpus callosum and consequently the telencephalon shows a different organization as compared to placental mammals. The rhinal fissure is located more dorsal in marsupials than in placental mammals and their anterior commissure is hypertrophied to communicate both hemispheres (Gloor, 1997). The olfactory epithelium (Kratzing, 1982) and olfactory bulbs are organized in a particular way in marsupials (Switzer and Johnson, 1977; Jia and Halpern, 2004). Olfactory projections were already investigated in the middle of twentieth century (Adey, 1953). The projections from the main and $\mathrm{AOBs}$ were described in opossums using the Fink-Heimer method (Scalia and Winans, 1975; Meyer, 1981; Shammah-Lagnado and Negrao, 1981). The olfactoryrecipient and vomeronasal-recipient cortices occupied adjacent non-overlapping areas. Using neural tracers, the projections from the opossum main (Martinez-Marcos and Halpern, 2006) and accessory (Martinez-Marcos and Halpern, 1999b) olfactory bulbs were later re-investigated using modern neural tracers. The projections from the MOB course mainly via the LOT to reach the anterior olfactory nucleus, olfactory tubercle, nucleus of the LOT, anterior and posterolateral cortical amygdaloid nuclei and the piriform, and lateral entorhinal cortices (Figure 4). The projections from the AOB course through the AOT to reach the medial amgydaloid complex and the posteromedial cortical amygdaloid nucleus (Figure 5). Both projections converge at rostral levels such as the medial amgydala, whereas are non-overlapping at caudal levels (Figure 6). The differential expression of $\mathrm{G}$ proteins in the vomeronasal system (Halpern et al., 1995) and the cloning of the two families of vomeronasal receptors (Dulac and Axel, 1995; Herrada and Dulac, 1997; Matsunami and Buck, 1997; Ryba and Tirindelli, 1997) allowed to identify the differential projections to the anterior and posterior portions of the AOB (Jia and Halpern, 1996; Belluscio et al., 1999; Rodriguez et al., 1999). Both portions send convergent but also differential projections to the vomeronasal amygdala in opossums (Martinez-Marcos and Halpern, 1999b), which are also reciprocated by differential centrifugal projections to the anterior and posterior divisions of the AOB (Martinez-Marcos and Halpern, 1999a).

\section{EUTHERIA, PLACENTAL MAMMALS}

In placental mammals, the projections from the olfactory epithelium to the MOB (Clark, 1951) and from the bulb to the cortex (Clark and Meyer, 1947) were already addressed in the middle of 

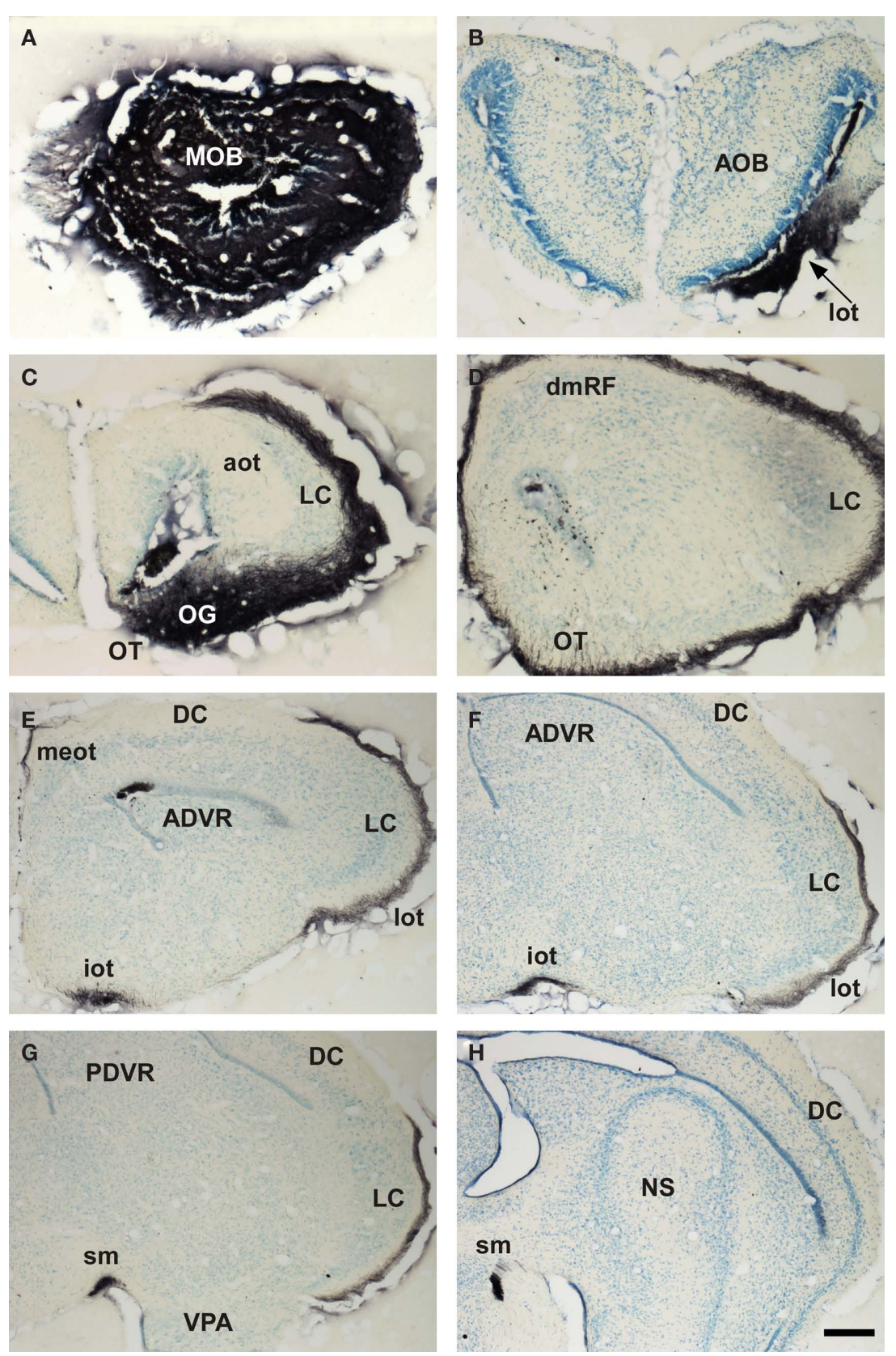

FIGURE 1 | Bright field microscopic images from rostral to caudal of coronal sections of one brain hemisphere showing biotinylated dextran-amine labeling Nissl-counterstained in the snake (Thamnophis sirtalis) olfactory cortices after one injection in the main olfactory bulb (MOB). (A) injection site in the MOB. (B-H) labeling in olfactory-recipient areas of the telencephalon. Scale bar $\mathbf{A}-\mathbf{D}=267 ; \mathbf{E}-\mathbf{H}=400 \mu \mathrm{m}$.

the twentieth century. The characterization of projections from the main and AOBs were reported later on (Heimer, 1968; Winans and Scalia, 1970; Raisman, 1972; Price, 1973; Scalia and Winans, 1975; Devor, 1976; Skeen and Hall, 1977; Kosel et al., 1981; Schoenfeld and Macrides, 1984; Shipley and Adamek, 1984; De Carlos et al., 1989) including the centrifugal projections (Davis et al., 1978; de Olmos et al., 1978; Davis and Macrides, 1981; Shipley and Adamek, 1984; Coolen and Wood, 1998). As in marsupials, the projections from the MOB form a minor projection through the MOT and a major projection through the LOT to reach the anterior olfactory nucleus, taenia tecta, olfactory tubercle, the nucleus of the LOT, rostral levels of the medial amgydaloid complex and the anterior and posterolateral cortical amygdaloid nuclei as well as the piriform and lateral entorhinal cortices (Figure 7). The projections from the AOB (Larriva-Sahd, 2008) travel through the AOT to reach the cortexamygdala-transition zone and the medial amgydaloid complex and posteromedial amygdaloid nucleus. Also, fibers course through the stria terminalis to reach the bed nucleus of the stria terminalis (Figure 8). Olfactory and vomeronasal projections converge at rostral levels of the basal telencephalon (Pro-Sistiaga et al., 2007) but not at 

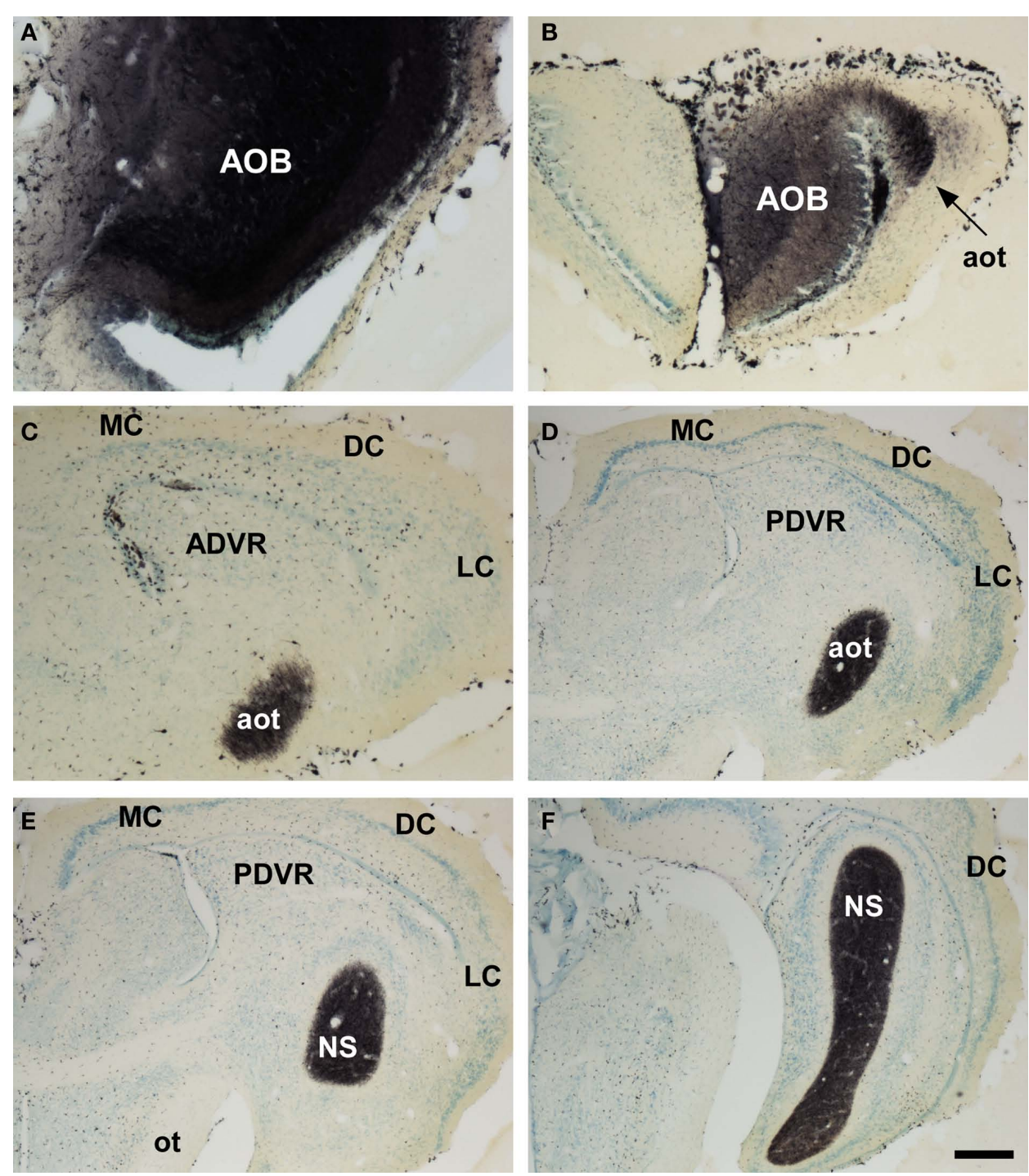

FIGURE 2 | Bright field microscopic images from rostral to caudal of coronal sections of one brain hemisphere showing biotinylated dextran-amine labeling Nissl-counterstained in the snake (Thamnophis sirtalis) vomeronasal amygdala after an injection in the accessory olfactory bulb (AOB). (A) injection site. (B-F) labeling in vomeronasal-recipient areas. Scale bar $\mathbf{A}=160 ; \mathbf{B}-\mathbf{C}=267 ; \mathbf{D}-\mathbf{E}=400 ; \mathbf{F}=533 \mu \mathrm{m}$.

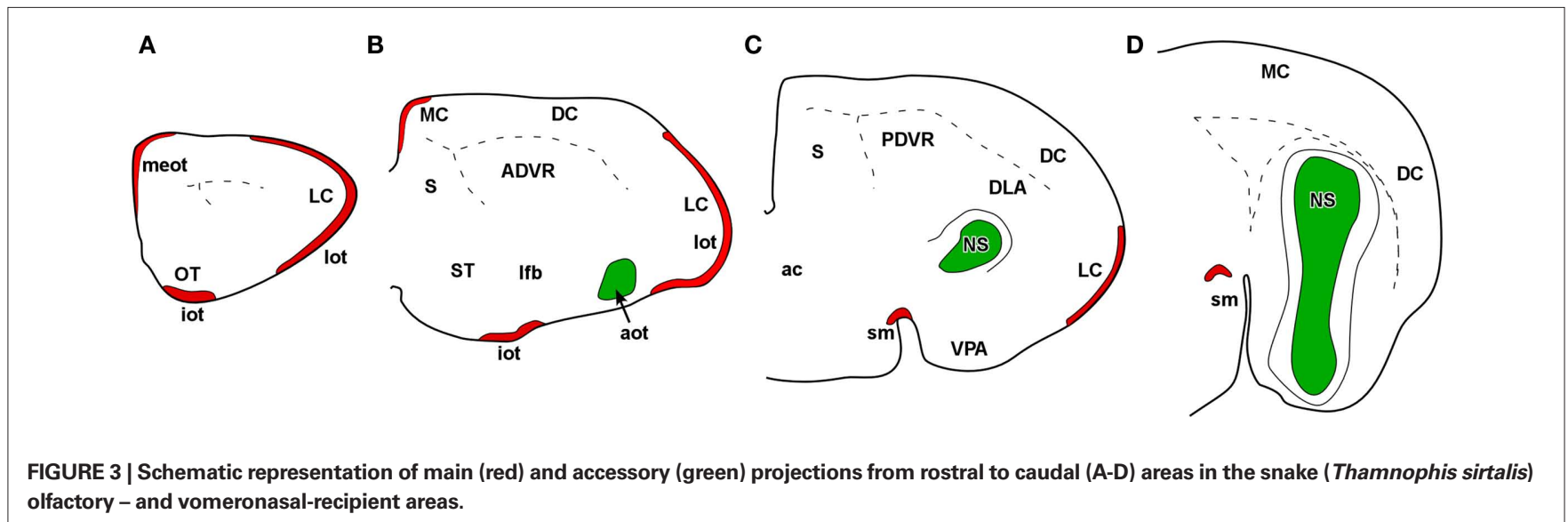



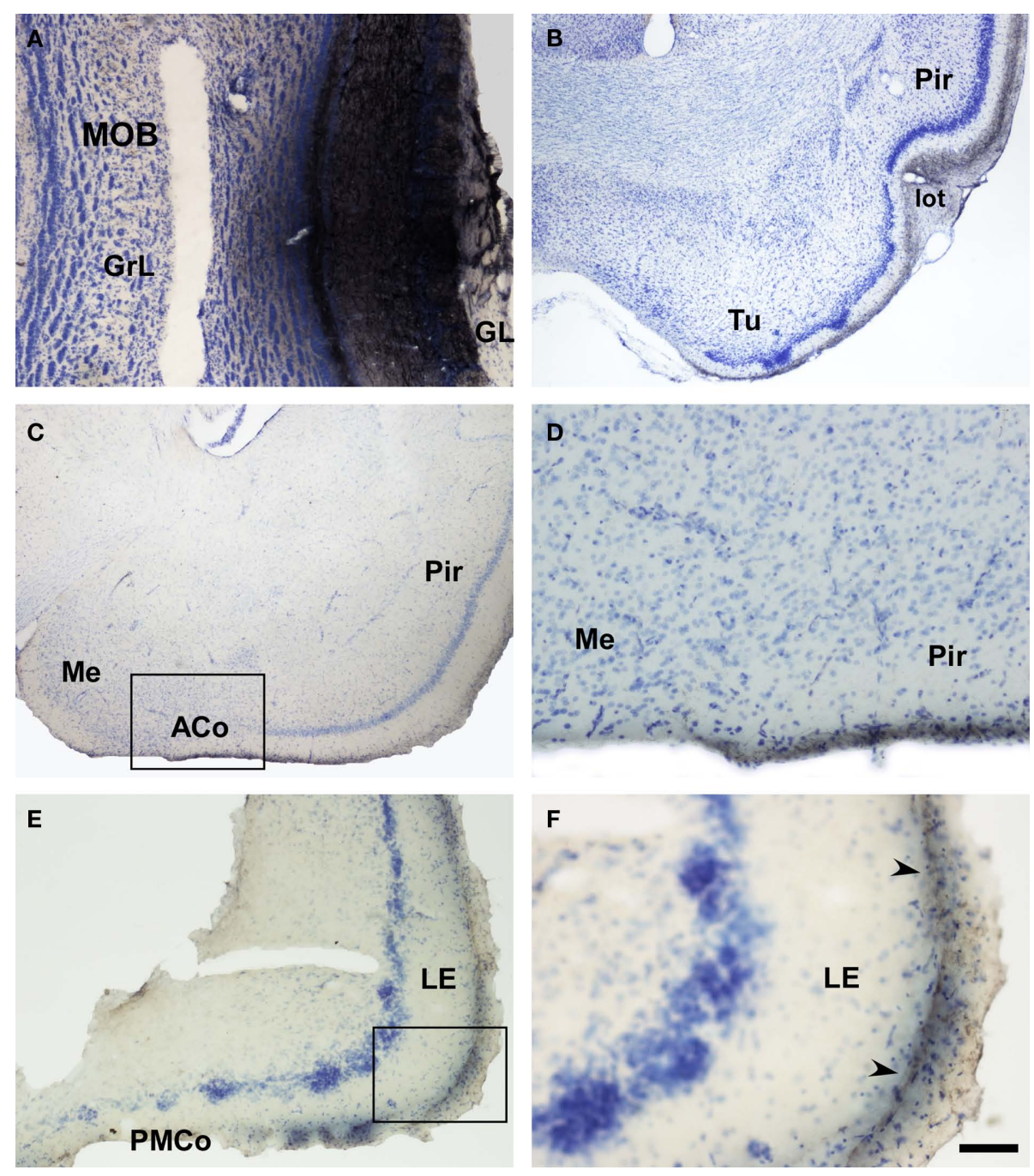

FIGURE 4 | Bright field microscopic images from rostral to caudal of coronal sections of one brain hemisphere showing biotinylated dextran-amine labeling Nissl-counterstained in the opossum (Monodelphis domestica) olfactory cortices after an injection in the main olfactory bulb (MOB). (A) injection site. (B-F) labeling in olfactory-recipient areas. Scale bar $\mathbf{A}, \mathbf{D}$, and $\mathbf{F}=160 ; \mathbf{B}, \mathbf{C}$, and $\mathbf{E}=800 \mu \mathrm{m}$.

caudal ones (Figure 9; Martinez-Marcos, 2009; Gutierrez-Castellanos et al., 2010). The differential expression of G proteins in the vomeronasal system (Halpern et al., 1995) and the cloning of two families of vomeronasal receptors (Dulac and Axel, 1995; Herrada and Dulac, 1997; Matsunami and Buck, 1997; Ryba and Tirindelli, 1997) led to the description of differential projections from the vomeronasal epithelium to the anterior and posterior divisions of the AOB (Jia and Halpern, 1996; Belluscio et al., 1999; Rodriguez et al., 1999). Both divisions of the $\mathrm{AOB}$ show convergent (Von Campenhause and Mori, 2000), but also partially divergent projections in the vomeronasal amygdala (Mohedano-Moriano et al., 2007) that are preserved in the hypothalamus (Mohedano-Moriano et al., 2008).

\section{PLATYRRHINI, NEW WORLD MONKEYS}

The MOB connections were recently characterized in the marmoset (Liebetanz et al., 2002). Injections of anterograde tracers revealed the medial and LOTs as well as the olfactory-recipient structures including the anterior olfactory nucleus, piriform cortex, tenia tecta, periamygdaloid cortex, and rostral entorhinal cortex. Centrifugal projections were also revealed originating in olfactory-recipient areas by using retrograde tracers. The vomeronasal system exists, but it is poorly developed in New World monkeys. In marmoset, that possess an intact vomeronasal organ, sequences of vomeronasal receptors (V1R) appear to correspond to pseudogenes (Giorgi and Rouquier, 2002). Neuron-specific markers have been reported to be expressed in the vomeronasal epithelium of different species of primates including marmoset (Dennis et al., 2004). Neurons in the AOB express markers typical of mitral/tufted cells (Nakajima et al., 2003). Marmoset, like other mammals and in contrast to rodents and opossums, display a homogeneous vomeronasal system where only V1R and Gi proteins are expressed (Takigami et al., 2004). To our knowledge, the secondary vomeronasal projections from the AOB have not been traced in marmosets. 

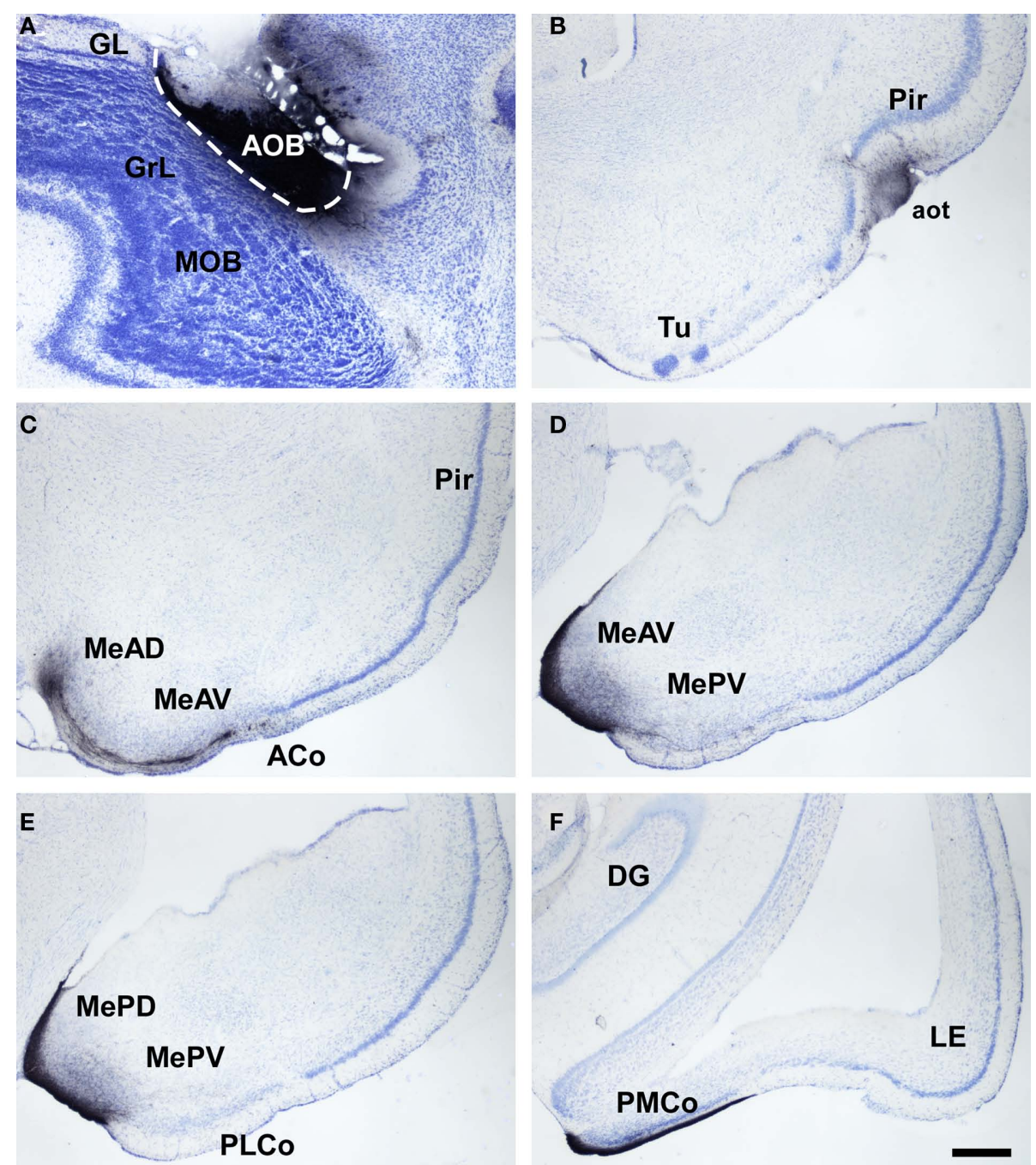

FIGURE 5 | Bright field microscope images from rostral to caudal of coronal (A is sagittal) sections of one brain hemisphere showing biotinylated dextran-amine labeling Nissl-counterstained in the opossum (Monodelphis domestica) vomeronasal cortices after an injection in the accessory olfactory bulb (AOB). (A) injection site. (B) labeling in vomeronasal-recipient areas. Scale bar $\mathbf{A}=400$; $\mathbf{B}-\mathbf{F}=800 \mu \mathrm{m}$.
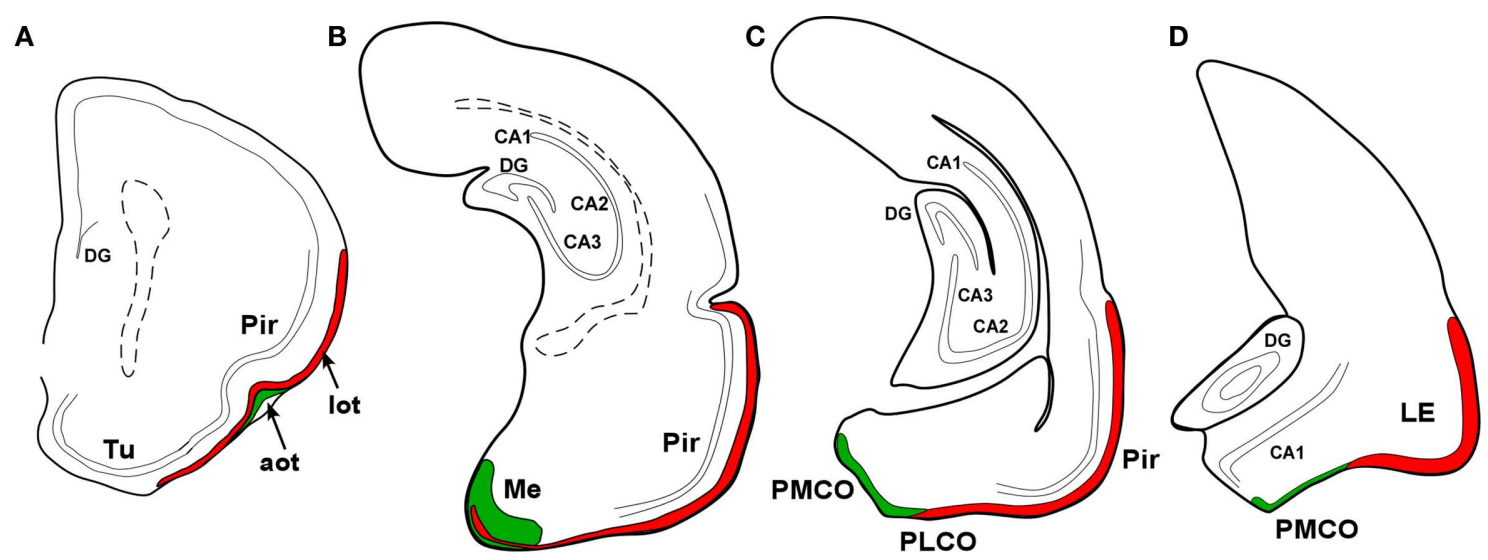

FIGURE 6 | Schematic representation of main (red) and accessory (green) projections from rostral to caudal (A-D) areas in the opossum (Monodelphis domestica) olfactory and vomeronasal cortices. 

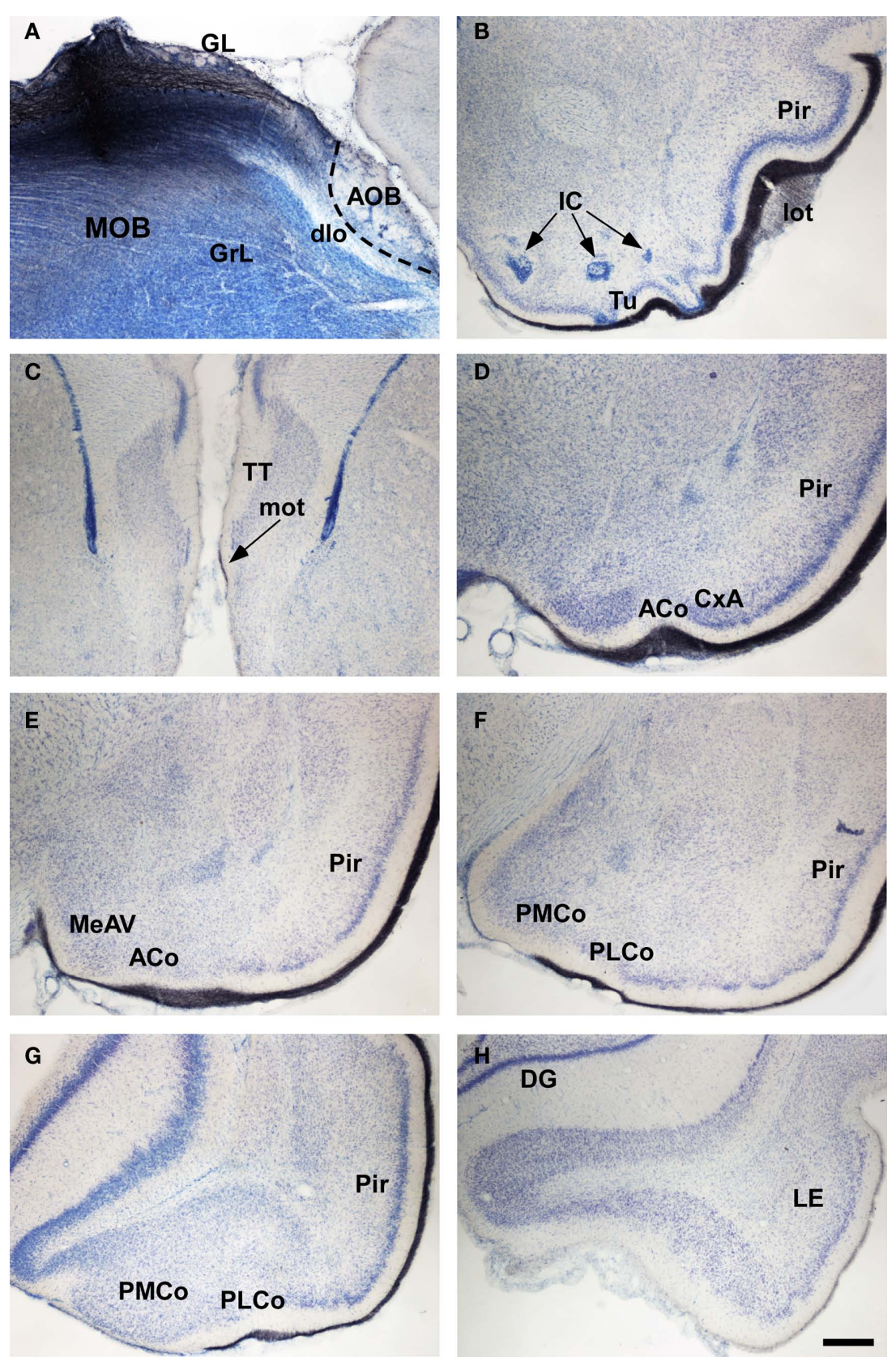

FIGURE 7| Bright field microscopic images from rostral to caudal of coronal ( $A$ is sagittal) sections of one brain hemisphere showing biotinylated dextran-amine labeling Nissl-counterstained in the rat (Rattus norvegicus) olfactory cortices after an injection in the main olfactory bulb (MOB).

(A) injection site. (B-H) labeling in olfactory-recipient areas. Scale bar $\mathbf{A}-\mathbf{B}$ and $\mathbf{D}-\mathbf{H}=800 ; \mathbf{C}=400 \mu \mathrm{m}$.

\section{CATARRHINI, OLD WORLD MONKEYS}

Olfactory receptors are quite reduced in humans and great apes including a $40 \%$ of pseudogenes (Sharon et al., 1999). The projections from the MOB were traced in Old World monkeys using lesion-degeneration, autoradiographic (Turner et al., 1978), and neural tracing (Carmichael et al., 1994; Mohedano-Moriano et al., 2005) techniques. Among structures identified as olfactoryrecipient were included the anterior olfactory nucleus, piriform cortex, ventral tenia tecta, olfactory tubercle, anterior cortical nucleus of the amygdala, periamygdaloid cortex, and olfactory division of the entorhinal cortex. Interestingly, olfactory fibers reach layer I of the medial amygdaloid complex. This structure has been traditionally described as a vomeronasal-recipient area, but recent data (Pro-Sistiaga et al., 2007; Kang et al., 2009) indicate that it is a mixed chemosensory structure receiving olfactory and vomeronasal inputs. Therefore, it could be hypothesized that this structure has changed from vomeronasal- to olfactory-recipient. Further investigations are needed to confirm this point (Figure 10). 

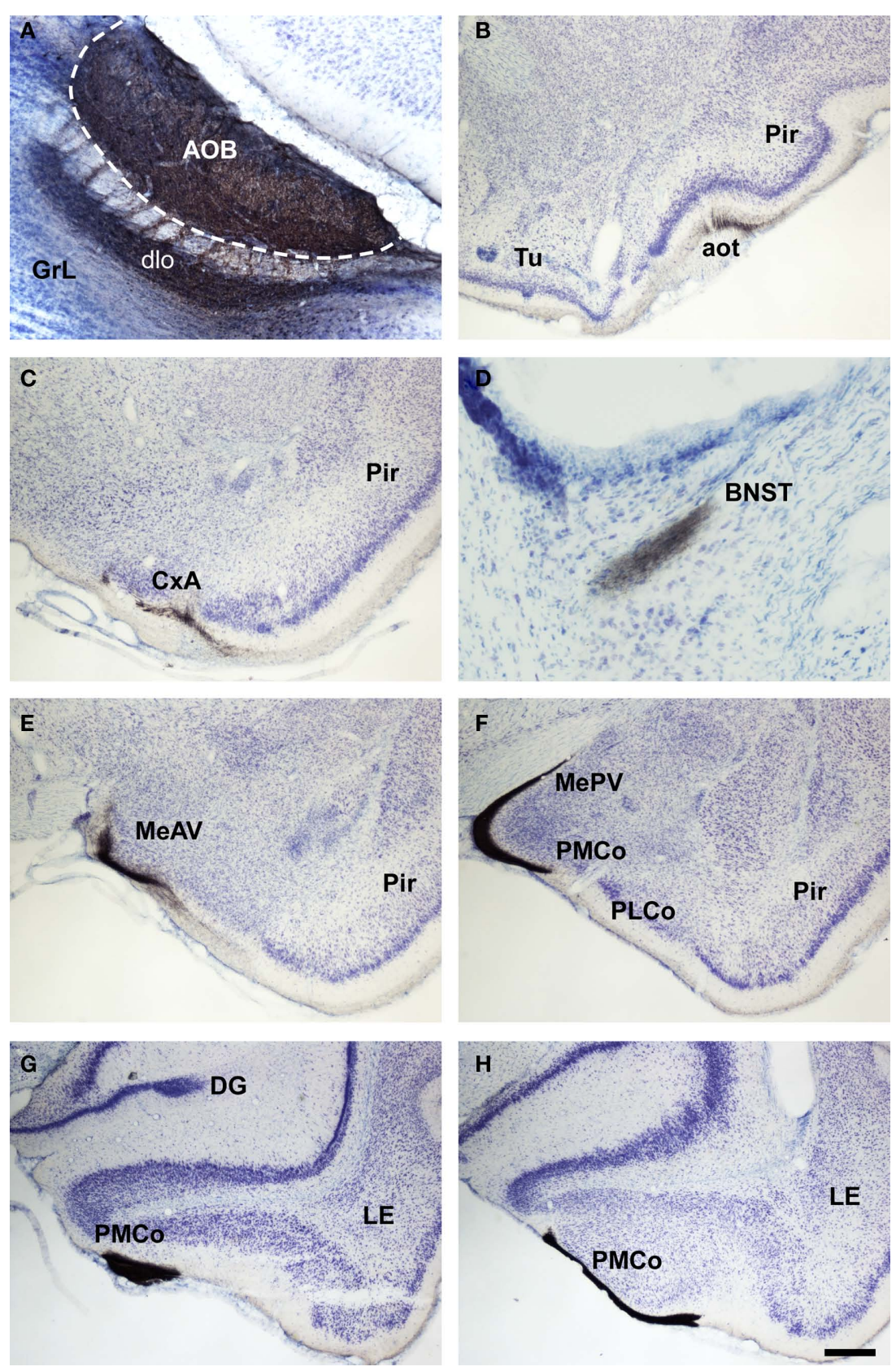

FIGURE 8 | Bright field microscopic images from rostral to caudal of coronal (A is sagittal) sections of one brain hemisphere showing biotinylated dextran-amine labeling Nissl-counterstained in the rat (Rattus norvegicus) vomeronasal cortices after an injection in the accessory olfactory bulb (AOB). (A) injection site. (B-H) labeling in vomeronasal-recipient areas. Scale bar $\mathbf{A}=400 ; \mathbf{B}-\mathbf{C}$ and $\mathbf{E}-\mathbf{H}=800 ; \mathbf{D}=160 \mu \mathrm{m}$.

\section{HOMINIDAE, HUMAN BEINGS}

Olfactory receptor genes have been identified in humans (Ben-Arie et al., 1994; Glusman et al., 1996, 2000; Buettner et al., 1998; Rouquier et al., 1998), although up to $40 \%$ appear to correspond to pseudogenes (Sharon et al., 1999). In fact, evolutionary pressures have led to the loss of part of the olfactory receptor repertoire (Young et al., 2002; Gilad et al., 2003; Niimura and Nei, 2003). The characterizations of olfactory projections in human have been only addressed by indirect methods such as comparative approaches with other primates (Insausti, 1993; Insausti et al., 2002). Putative olfactory areas include the same structures identified in other primates such as anterior olfactory nucleus, piriform cortex, ventral tenia tecta, olfactory tubercle, anterior cortical nucleus of the amygdala, periamygdaloid cortex, and olfactory division of the entorhinal cortex. In humans, the vomeronasal system is vestigial. The vomeronasal organ is apparently only present during embryonic development and its presence is quite controversial in adult humans (Stensaas et al., 1991; Smith et al., 1998, 2001; Smith and Bhatnagar, 2000; Trotier et al., 2000; Abolmaali et al., 
A

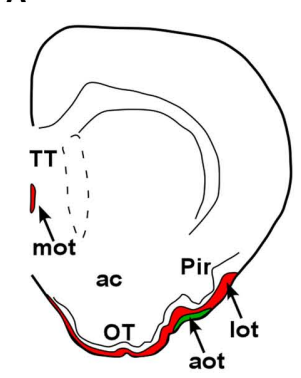

B

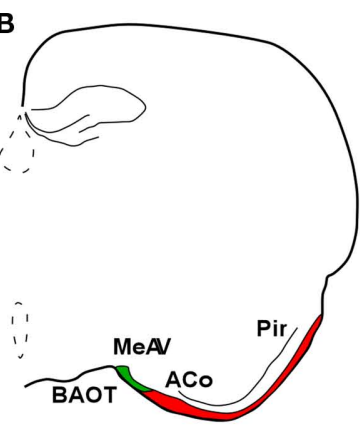

C

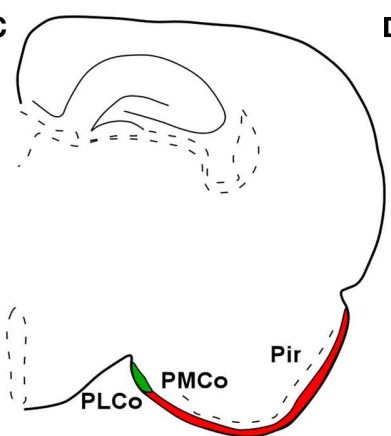

D

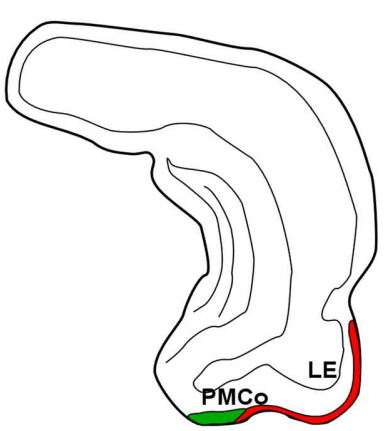

FIGURE 9 | Schematic representation of main (red) and accessory (green) projections from rostral to caudal (A-D) areas in the rat (Rattus norvegicus) olfactory and vomeronasal cortices.

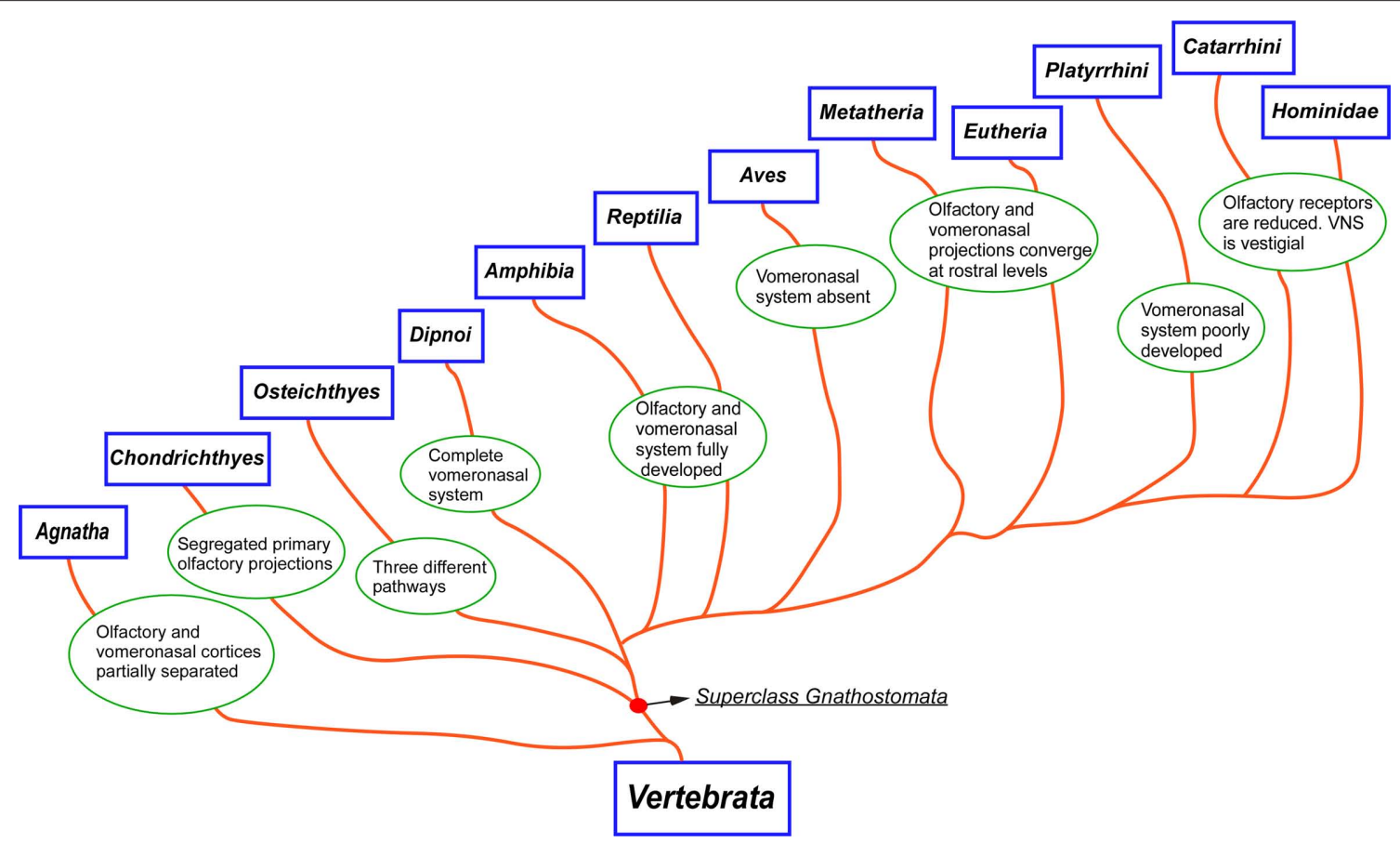

FIGURE 10 | Cladogram illustrating the main taxa analyzed in the present report and the main changes in the olfactory and vomeronasal systems occurred during evolution.

2001; Bhatnagar and Smith, 2001; Knecht et al., 2001,2003; Meredith, 2001; Witt et al., 2002; Besli et al., 2004; Witt and Hummel, 2006; Witt and Wozniak, 2006). Putative pheromone receptors have been identified in human olfactory mucosa (Rodriguez et al., 2000; Rodriguez and Mombaerts, 2002). Further, to our knowledge, the human AOB has not been described. Therefore, the human "pheromonal-like" behaviors are probably mediated through the olfactory system (Mast and Samuelsen, 2009; Savic et al., 2009).

\section{CONCLUSION}

Olfaction plays a main role in most vertebrate taxa. Cladistic analysis of different vertebrates indicates that during evolution an early anatomical and functional subdivision of nasal chemical systems occurred - mainly olfactory and vomeronasal systems - including different receptors, and primary and secondary projection areas. The different chemical systems have suffered differential involution in given taxa due to evolutionary pressures.

\section{ACKNOWLEDGMENTS}

This work has been funded by the Spanish Ministry of Education and Science-FEDER (BFU2007-67912-CO2-01/ BFI to Fernando Martinez-Garcia and BFU2007-62290/BFI to Alino Martinez-Marcos) and the Autonomous Government of Castilla-La Mancha (PCC08-0064 to Alino Martinez-Marcos and Enrique Lanuza). 


\section{REFERENCES}

Abellan, A., Legaz, I., Vernier, B., Retaux, S., and Medina, L. (2009). Olfactory and amygdalar structures of the chicken ventral pallium based on the combinatorial expression patterns of LIM and other developmental regulatory genes. Comp. J. Neurol. 516, 166-186.

Abolmaali, N. D., Kuhnau, D., Knecht, M., Kohler, K., Huttenbrink, K. B., and Hummel, T. (2001). Imaging of the human vomeronasal duct. Chem. Senses 26, 35-39.

Ache, B. W., and Young, J. M. (2005). Olfaction: diverse species, conserved principles. Neuron 48, 417-430.

Adey, W. R. (1953). An experimental study of the central olfactory connexions in a marsupial (Trichosurus Vulpecula). Brain 76, 311-330.

Alonso, J. R., Covenas, R., Lara, J. Arevalo, R., de Leon, M., and Aijon, J. (1989). Tyrosine hydroxylase immunoreactivity in a subpopulation of granule cells in the olfactory bulb of teleost fish. Brain Behav. Evol. 34, 318-324.

Balthazart, J., and Taziaux, M. (2009). The underestimated role of olfaction in avian reproduction? Behav. Brain Res. 200, 248-259.

Bargmann, C. I. (1997). Olfactory receptors, vomeronasal receptors, and the organization of olfactory information. Cell 90, 585-587.

Bargmann, C. I. (1999). A complex sensory map for pheromones. Neuron 22 , 640-642.

Bargmann, C. I. (2006). Comparative chemosensation from receptors to ecology. Nature 444, 295-301.

Belluscio, L., Koentges, G., Axel, R., and Dulac, C. (1999). A map of pheromone receptor activation in the mammalian brain. Cell 97, 209-220.

Ben-Arie, N., Lancet, D., Taylor, C., Khen, M., Walker, N., Ledbetter, D. H., Carrozzo, R., Patel, K., Sheer, D., Lehrach, H., and North, M. (1994). Olfactory receptor gene cluster on human chromosome 17: possible duplication of an ancestral receptor repertoire. Hum. Mol. Genet. 3, 229-235.

Besli, R., Saylam, C., Veral, A., Karl, B., and Ozek, C. (2004). The existence of the vomeronasal organ in human beings. J. Craniofac. Surg. $15,730-735$.

Bhatnagar, K. P., and Smith, T. D. (2001). The human vomeronasal organ. III. Postnatal development from infancy to the ninth decade. J. Anat. 199 289-302.

Brennan, P. A., and Keverne, E. B. (2004). Something in the air? New insights into mammalian pheromones. Curr. Biol. 14, R81-R89.
Brennan, P. A., and Zufall, F. (2006). Pheromonal communication in vertebrates. Nature 444, 308-315.

Brox, A., Puelles, L., Ferreiro, B., and Medina, L. (2004). Expression of the genes Emx1, Tbr1, and Eomes (Tbr2) in the telencephalon of Xenopus laevis confirms the existence of a ventral pallial division in all tetrapods. J. Comp. Neurol. 474, 562-577.

Buck, L., and Axel, R. (1991). A novel multigene family may encode odorant receptors: a molecular basis for odor recognition. Cell 65, 175-187.

Buck, L. B. (1995). Unraveling chemosensory diversity. Cell 83, 349-352.

Buck, L. B. (1996). Information coding in the vertebrate olfactory system. Annu. Rev. Neurosci. 19, 517-544.

Buck, L. B. (2000). The molecular architecture of odor and pheromone sensing in mammals. Cell 100, 611-618.

Buck, L. B. (2004). Olfactory receptors and odor coding in mammals. Nutr. Rev. 62, S184-S188; discussion S141-S224.

Buettner, J. A., Glusman, G., Ben-Arie, N., Ramos, P., Lancet, D., and Evans, G. A. (1998). Organization and evolution of olfactory receptor genes on human chromosome 11. Genomics 53, 56-68.

Butler, A. B. (2000). Topography and topology of the teleost telencephalon: a paradox resolved. Neurosci. Lett. 293, 95-98.

Carmichael, S. T., Clugnet, M. C., and Price, J. L. (1994). Central olfactory connections in the macaque monkey. J. Comp. Neurol. 346, 403-434.

Caro, S. P., and Balthazart, J. (2010) Pheromones in birds: myth or reality? J. Comp. Physiol. 196, 751-766.

Chiba, A. (1999). Immunohistochemical distribution of neuropeptide Y-related substance in the brain and hypophysis of the arctic lamprey, Lethenteron japonica. Brain Behav. Evol. 53 102-109.

Clark, W.E. (1951). The projection of the olfactory epithelium on the olfactory bulb in the rabbit. J. Neurol. Neurosurg. Psychiatry 14, 1-10.

Clark, W. E., and Meyer, M. (1947). The terminal connexions of the olfactory tract in the rabbit. Brain 70 , 304-328.

Cleland, T. A. (2010). Early transformations in odor representation. Trends Neurosci. 33, 130-139.

Cobb, S. (1960). A note on the size of the avian olfactory bulb. Epilepsia 1, 394-402.

Coolen, L. M., and Wood, R. I. (1998). Bidirectional connections of the medial amygdaloid nucleus in the Syrian hamster brain: simultaneous anterograde and retrograde tract tracing. J. Comp. Neurol. 399, 189-209.

Crowe, M. J., and Pixley, S. K. (1992) Species differences in amphibian olfactory neuron reactivity to a monoclonal antibody. Brain Res. Bull. 28 785-788.

Daston, M. M., Adamek, G. D., and Gesteland,R.C.(1990).Ultrastructural organization of receptor cell axons in frog olfactory nerve. Brain Res. 537, 69-75.

Date-Ito, A., Ohara, H., Ichikawa, M., Mori, Y., and Hagino-Yamagishi, K. (2008). Xenopus V1R vomeronasal receptor family is expressed in the main olfactory system. Chem. Sense 33, 339-346.

Davis, B. J., and Macrides, F. (1981). The organization of centrifugal projections from the anterior olfactory nucleus, ventral hippocampal rudiment, and piriform cortex to the main olfactory bulb in the hamster: an autoradiographic study. J. Comp. Neurol. 203 , 475-493.

Davis, B. J., Macrides, F., Youngs, W. M., Schneider, S. P., and Rosene, D. L. (1978). Efferents and centrifugal afferents of the main and accessory olfactory bulbs in the hamster. Brain Res. Bull. 3, 59-72.

De Carlos, J. A., Lopez-Mascaraque, L. and Valverde, F. (1989). Connections of the olfactory bulb and nucleus olfactorius anterior in the hedgehog (Erinaceus europaeus): fluorescen tracers and HRP study. J. Comp. Neurol. 279, 601-618.

de Olmos, J., Hardy, H., and Heimer, L. (1978). The afferent connections of the main and the accessory olfactory bulb formations in the rat: an experimental HRP-study. J. Comp. Neurol. 181, 213-244.

Dennis, J. C., Smith, T. D., Bhatnagar, K. P., Bonar, C. J., Burrows, A. M., and Morrison, E. E. (2004). Expression of neuron-specific markers by the vomeronasal neuroepithelium in six species of primates. Anat. Rec. 281, 1190-1200.

Devor, M. (1976). Fiber trajectories of olfactory bulb efferents in the hamster. J. Comp. Neurol. 166, 31-47.

Dietl, M. M., and Palacios, J. M. (1988). Neurotransmitter receptors in the avian brain. I. Dopamine receptors. Brain Res. 439, 354-359.

Duchamp-Viret, P., and Duchamp, A (1997). Odor processing in the frog olfactory system. Prog. Neurobiol. 53 , 561-602.

Dulac, C. (1997). Molecular biology of pheromone perception in mammals. Semin. Cell Dev. Biol. 8, 197-205.

Dulac, C. (2000). Sensory coding of pheromone signals in mammals. Curr Opin. Neurobiol. 10, 511-518.
Dulac, C., and Axel, R. (1995). A nove family of genes encoding putative pheromone receptors in mammals. Cell 83, 195-206.

Dulac, C., and Torello, A. T. (2003). Molecular detection of pheromone signals in mammals: from genes to behaviour. Nat. Rev. Neurosci. 4, 551-562.

Dulac, C., and Wagner, S. (2006). Genetic analysis of brain circuits underlying pheromone signaling. Annu. Rev. Genet. 40, 449-467.

Ebinger, P., Rehkamper, G., and Schroder, H. (1992). Forebrain specialization and the olfactory system in anseriform birds. An architectonic and tracing study. Cell Tissue Res. 268, 81-90.

Eisthen, H. L. (1997). Evolution of vertebrate olfactory systems. Brain Behav. Evol. 50, 222-233.

Ferrando, S., Bottaro, M., Gallus, L., Girosi, L., Vacchi, M., and Tagliafierro, G. (2006). Observations of crypt neuronlike cells in the olfactory epithelium of a cartilaginous fish. Neurosci. Lett. 403, 280-282.

Ferrando, S., Bottaro, M., Gallus, L., Girosi, L., Vacchi, M., and Tagliafierro, G. (2007). First detection of olfactory marker protein (OMP) immunoreactivity in the olfactory epithelium of a cartilaginous fish. Neurosci. Lett. 413, 173-176.

Ferrando, S., Gambardella, C., Ravera, S., Bottero, S., Ferrando, T., Gallus, L., Manno, V., Salati, A. P., Ramoino, P., and Tagliafierro, G. (2009). Immunolocalization of G-protein alpha subunits in the olfactory system of the cartilaginous fish Scyliorhinus canicula. Anat. Rec. (Hoboken) 292, 1771-1779.

Fine, J. M., and Sorensen, P. W. (2008). Isolation and biological activity of the multi-component sea lamprey migratory pheromone. J. Chem. Ecol. 34, 1259-1267.

Finger, T. E. (1975). The distribution of the olfactory tracts in the bullhead catfish, Ictalurus nebulosus. J. Comp. Neurol. 161, 125-141.

Folgueira, M., Anadon, R., and Yanez, J. (2004). An experimental study of the connections of the telencephalon in the rainbow trout (Oncorhynchus mykiss). I: olfactory bulb and ventral area. J. Comp. Neurol. 480, 180-203.

Gagliardo, A., Ioale, P., Savini, M., and Wild, J. M. (2009). Olfactory navigation in homing pigeons: the last challenge. Ann. N.Y. Acad. Sci. 1170, 434-437.

Gaikwad, A., Biju, K. C., Saha, S. G., and Subhedar, N. (2004). Neuropeptide Y in the olfactory system, forebrain and pituitary of the teleost, Clarias batrachus. J. Chem. Neuroanat. 27, 55-70. 
Gamble, H. J. (1952). An experimental study of the secondary olfactory connexions in Lacerta viridis. J. Anat. 86, 180-196.

Gamble, H. J. (1956). An experimental study of the secondary olfactory connexions in Testudo graeca. J. Anat. 90, 15-29.

Getchell, M. L., Bouvet, J. F., Finger, T. E., Holley, A., and Getchell, T. V. (1989). Peptidergic regulation of secretory activity in amphibian olfactory mucosa: immunohistochemistry, neural stimulation, and pharmacology. Cell Tissue Res. 256, 381-389.

Gilad, Y., Man, O., Paabo, S., and Lancet, D. (2003). Human specific loss of olfactory receptor genes. Proc. Natl. Acad. Sci. U.S.A. 100, 3324-3327.

Giorgi, D., and Rouquier, S. (2002). Identification of V1R-like putative pheromone receptor sequences in nonhuman primates. Characterization of V1R pseudogenes in marmoset, a primate species that possesses an intact vomeronasal organ. Chem. Senses 27, 529-537.

Gloor, P. (1997). The Temporal Lobe and Limbic System. New York: Oxford University Press.

Glusman, G., Clifton, S., Roe, B., and Lancet, D. (1996). Sequence analysis in the olfactory receptor gene cluster on human chromosome 17: recombinatorial events affecting receptor diversity. Genomics 37, 147-160.

Glusman, G., Sosinsky, A., Ben-Asher, E., Avidan, N., Sonkin, D., Bahar, A., Rosenthal,A., Clifton, S., Roe, B., Ferraz, C., Demaille, J., and Lancet, D. (2000). Sequence, structure, and evolution of a complete human olfactory receptor gene cluster. Genomics 63, 227-245.

Goel, H. R. (1978). The structure and functions of the olfactory organs in the fresh water teleost Notopterus notopterus (HAM). Folia Morphol. 26, 392-396.

Gonzalez, A., Morona, R., Lopez, M. J., Moreno, N., and Northcutt, R. G. (2010). Lungfishes, like tetrapods, possess a vomeronasal system. Front. Neuroanat. 4:130. doi: 10.3389/ fnana.2010.00130

Gonzalez, A., and Smeets, W. J. (1991). Comparative analysis of dopamine and tyrosine hydroxylase immunoreactivities in the brain of two amphibians, the anuran Rana ridibunda and the urodele Pleurodeles waltlii. J. Comp. Neurol. 303, 457-477.

Grus, W. E., and Zhang, J. (2009). Origin of the genetic components of the vomeronasal system in the common ancestor of all extant vertebrates. $\mathrm{Mol}$. Biol. Evol. 26, 407-419.

Gutierrez-Castellanos, N., MartinezMarcos, A., Martinez-Garcia, F., and Lanuza, E. (2010). Chemosensory function of the amygdala. Vitam. Horm. 83, 165-196.

Halpern, M. (1976). The efferent connections of the olfactory bulb and accessory olfactory bulb in the snakes, Thamnophis sirtalis and Thamnophis radix. J. Morphol. 150, 553-578.

Halpern, M., Shapiro, L. S., and Jia, C. (1995). Differential localization of G proteins in the opossum vomeronasal system. Brain Res. 677, 157-161.

Hamdani el, H., and Doving, K. B. (2007). The functional organization of the fish olfactory system. Prog. Neurobiol. 82, 80-86.

Hara, T. J. (1975). Olfaction in fish. Prog. Neurobiol. 5, 271-335.

Heimer, L. (1968). Synaptic distribution of centripetal and centrifugal nerve fibres in the olfactory system of the rat. An experimental anatomical study. J. Anat. 103, 413-432.

Herrada, G., and Dulac, C. (1997). A novel family of putative pheromone receptors in mammals with a topographically organized and sexually dimorphic distribution. Cell 90, 763-773.

Hickman, C. P., Roberts, L. S., and Larson, A. (2007). Integrated Principles of Zoololgy. New York: McGraw-Hill.

Insausti, R. (1993). Comparative anatomy of the entorhinal cortex and hippocampus in mammals. Hippocampus 3, 19-26.

Insausti, R., Marcos, P., Arroyo-Jimenez, M. M., Blaizot, X., and MartinezMarcos, A. (2002). Comparative aspects of the olfactory portion of the entorhinal cortex and its projection to the hippocampus in rodents, nonhuman primates, and the human brain. Brain Res. Bull. 57, 557-560.

Ioale, P., and Papi, F. (1989). Olfactory bulb size, odor discrimination and magnetic insensitivity in hummingbirds. Physiol. Behav. 45, 995-999.

Iwahori, N., Kiyota, E., and Nakamura, K. (1987a). A Golgi study on the olfactory bulb in the lamprey, Lampetra japonica. Neurosci. Res. 5, 126-139.

Iwahori, N., Kiyota, E., and Nakamura, K. (1987b). Olfactory and respiratory epithelia in the snake, Elaphe quadrivirgata. Okajimas Folia Anat. Jpn. 64, 183-191.

Iwahori, N., Nakamura, K., and Mameya, C. (1989a). A Golgi study on the accessory olfactory bulb in the snake, Elaphe quadrivirgata. Neurosci. Res. 7, 55-70.

Iwahori, N., Nakamura, K., and Mameya, C. (1989b). A Golgi study on the main olfactory bulb in the snake Elaphe quadrivirgata. Neurosci. Res. 6, 411-425.

Jain, V.K., and Sahai, S. (1991).Anatomical and histochemical studies of the olfactory apparatus of three teleost fishes and its significance in their behaviour. Funct. Dev. Morphol. 1, 21-26.

Jia, C., and Halpern, M. (1996). Subclasses of vomeronasal receptor neurons: differential expression of $G$ proteins (Gi alpha 2 and G(o alpha)) and segregated projections to the accessory olfactory bulb. Brain Res. 719, 117-128.

Jia, C., and Halpern, M. (2004). Calbindin D28k, parvalbumin, and calretinin immunoreactivity in the main and accessory olfactory bulbs of the gray short-tailed opossum, Monodelphis domestica. J. Morphol. 259, 271-280.

Jungblut, L. D., Paz, D. A., LopezCosta, J. J., and Pozzi, A. G. (2009). Heterogeneous distribution of $\mathrm{G}$ protein alpha subunits in the main olfactory and vomeronasal systems of Rhinella (Bufo) arenarum tadpoles. Zool. Sci. 26, 722-728.

Kang, N., Baum, M. J., and Cherry, J. A. (2009). A direct main olfactory bulb projection to the 'vomeronasal' amygdala in female mice selectively responds to volatile pheromones from males. Eur. J. Neurosci. 29, 624-634.

Kaupp, U. B. (2010). Olfactory signalling in vertebrates and insects: differences and commonalities. Nat. Rev. Neurosci. 11, 188-200.

Knecht, M., Kuhnau, D., Huttenbrink, B. K., Witt, M., and Hummel, T. (2001). Frequency and localization of the putative vomeronasal organ in humans in relation to age and gender. Laryngoscope 111, 448-452.

Knecht, M., Lundstrom, J. N., Witt, M. Huttenbrink, K. B., Heilmann, S., and Hummel, T. (2003). Assessment of olfactory function and androstenone odor thresholds in humans with or without functional occlusion of the vomeronasal duct. Behav. Neurosci. 117, 1135-1141.

Kondoh, D., Yamamoto, Y., Nakamuta, N., and Taniguchi, K. (2010). Lectin histochemical studies on the olfactory epithelium and vomeronasal organ in the Japanese striped snake, Elaphe quadrivirgata. J. Morphol. 271, 1197-1203.

Kosaka, T., and Hama, K. (1982). Synaptic organization in the teleost olfactory bulb. J. Physiol. 78, 707-719.

Kosaka, T., Kosaka, K., and Nagatsu, I. (1991). Tyrosine hydroxylase-like immunoreactive neurons in the olfactory bulb of the snake, Elaphe quadrivirgata, with special reference to the colocalization of tyrosine hydroxylaseand GABA-like immunoreactivities. Exp. Brain Res. 87, 353-362.

Kosel, K. C., Van Hoesen, G. W., and West, J.R. (1981). Olfactory bulb projections to the parahippocampal area of the rat. J. Comp. Neurol. 198, 467-482.

Kratzing, J. E. (1982). Regional variation in respiratory epithelium of the nasal cavity of the bandicoot (Isoodon macrourus). J. Anat. 134, 1-9.

Krishna, N. S., Getchell, T. V., Margolis, F. L., and Getchell, M. L. (1992). Amphibian olfactory receptor neurons express olfactory marker protein. Brain Res. 593, 295-298.

Laberge, F., and Hara, T. J. (2001) Neurobiology of fish olfaction: a review. Brain Res. Rev. 36, 46-59.

Laframboise, A. J., Ren, X., Chang, S., Dubuc, R., and Zielinski, B. S. (2007). Olfactory sensory neurons in the sea lamprey display polymorphisms. Neurosci. Lett. 414, 277-281.

Lanuza, E., and Halpern, M. (1998). Efferents and centrifugal afferents of the main and accessory olfactory bulbs in the snake Thamnophis sirtalis. Brain Behav. Evol. 51, 1-22.

Larriva-Sahd, J. (2008). The accessory olfactory bulb in the adult rat: a cytological study of its cell types, neuropil, neuronal modules, and interactions with the main olfactory system. $J$. Comp. Neurol. 510, 309-350.

Liberles, S. D., and Buck, L. B. (2006). A second class of chemosensory receptors in the olfactory epithelium. Nature 442, 645-650.

Liebetanz, D., Nitsche, M. A., Fromm, C., and Reyher, C. K. (2002). Central olfactory connections in the microsmatic marmoset monkey (Callithrix jacchus). Cells Tissues Organs 172, 53-69.

Lohman, A. H., Hoogland, P. V., and Witjes, R. J.G. M. (1988). "Projections from the main and accessory olfactory bulbs to the amygdaloid complex in the lizard gekko gecko," in The Forebrain or Reptiles, eds W. K. Schwerdtfeger and J.W. Smeets (Basel: Karger), 41-49.

Lohman, A. H., and Smeets, W. J. (1993). Overview of the main and accessory olfactory bulb projections in reptiles. Brain Behav. Evol. 41, 147-155.

Marin, O., Smeets, W. J., and Gonzalez, A. (1997). Distribution of choline acetyltransferase immunoreactivity in the brain of anuran (Ranaperezi, Xenopus laevis) and urodele (Pleurodeles waltl) amphibians. J. Comp. Neurol. 382, 499-534.

Martinez-Garcia, F., Martinez-Marcos, A., and Lanuza, E. (2002). The pallial amygdala of amniote vertebrates: evolution of the concept, evolution of the structure. Brain Res. Bull. 57, 463-469.

Martinez-Garcia, F., Olucha, F. E., Teruel, V., and Lorente, M. J. (1993). Fiber connections of the amygdaloid formation of the lizard Podarcis hispanica. Brain Behav. Evol. 41, 156-162.

Martinez-Garcia, F., Olucha, F. E., Teruel, V., Lorente, M. J., and Schwerdtfeger, W. K. (1991). Afferent and efferent 
connections of the olfactory bulbs in the lizard Podarcis hispanica. J. Comp. Neurol. 305, 337-347.

Martinez-Marcos, A. (2009). On the organization of olfactory and vomeronasal cortices. Prog. Neurobiol. 87, 21-30.

Martinez-Marcos, A., and Halpern, M. (1999a). Differential centrifugal afferents to the anterior and posterior accessory olfactory bulb. Neuroreport 10, 2011-2015.

Martinez-Marcos, A., and Halpern, M. (1999b). Differential projections from the anterior and posterior divisions of the accessory olfactory bulb to the medial amygdala in the opossum, Monodelphis domestica. Eur. J. Neurosci. 11, 3789-3799.

Martinez-Marcos, A., and Halpern, M. (2006). Efferent connections of the main olfactory bulb in the opossum (Monodelphis domestica): a characterization of the olfactory entorhinal cortex in a marsupial. Neurosci. Lett. 395, 51-56.

Martinez-Marcos, A., Lanuza, E., and Halpern, M. (1999). Organization of the ophidian amygdala: chemosensory pathways to the hypothalamus. J. Comp. Neurol. 412, 51-68.

Mast, T. G., and Samuelsen, C. L. (2009). Human pheromone detection by the vomeronasal organ: unnecessary for mate selection? Chem. Senses 34, 529-531.

Matsunami, H., and Buck, L. B. (1997). A multigene family encoding a diverse array of putative pheromone receptors in mammals. Cell 90, 775-784.

Melendez-Ferro, M., Perez-Costas, E. Rodriguez-Munoz, R., Gomez-Lopez, M. P., Anadon, R., and Rodicio, M. C. (2001). GABA immunoreactivity in the olfactory bulbs of the adult sea lamprey Petromyzon marinus L. Brain Res. 893, 253-260.

Meredith, M. (2001). Human vomeronasal organ function: a critical review of best and worst cases. Chem. Senses 26, 433-445.

Meyer, R. P. (1981). Central connections of the olfactory bulb in the American opossum (Didelphys virginiana): a light microscopic degeneration study. Anat. Rec. 201, 141-156.

Miyasaka, N., Morimoto, K., Tsubokawa, T., Higashijima, S., Okamoto, H., and Yoshihara, Y. (2009). From the olfactory bulb to higher brain centers: genetic visualization of secondary olfactory pathways in zebrafish. $J$. Neurosci. 29, 4756-4767.

Mohedano-Moriano, A., MartinezMarcos, A., Munoz, M., ArroyoJimenez, M. M., Marcos, P., Artacho-Perula, E., Blaizot, X., and Insausti, R. (2005). Reciprocal connections between olfactory structures and the cortex of the rostral superior temporal sulcus in the Macaca fascicularis monkey. Eur. J. Neurosci. 22, 2503-2518.

Mohedano-Moriano, A., Pro-Sistiaga, P., Ubeda-Banon, I., Crespo, C., Insausti, R., and Martinez-Marcos, A. (2007). Segregated pathways to the vomeronasal amygdala: differential projections from the anterior and posterior divisions of the accessory olfactory bulb. Eur. J. Neurosci. 25, 2065-2080.

Mohedano-Moriano, A., Pro-Sistiaga, P., Ubeda-Banon, I., de la Rosa-Prieto, C., Saiz-Sanchez, D., and MartinezMarcos, A. (2008). V1R and V2R segregated vomeronasal pathways to the hypothalamus. Neuroreport 19 , 1623-1626.

Mombaerts, P. (1996). Targeting olfaction. Curr. Opin. Neurobiol. 6, 481-486.

Mombaerts, P. (1999a). Molecular biology of odorant receptors in vertebrates. Ann. Rev. Neurosci. 22, 487-509.

Mombaerts, P. (1999b). Seventransmembrane proteins as odorant and chemosensory receptors. Science 286, 707-711.

Mombaerts, P. (2004). Genes and ligands for odorant, vomeronasal and taste receptors. Nat. Rev. Neurosci. 5, 263-278.

Mombaerts, P., Wang, F., Dulac, C., Chao, S. K., Nemes, A., Mendelsohn, M., Edmondson, J., and Axel, R. (1996). Visualizing an olfactory sensory map. Cell 87, 675-686.

Moreno, N., and Gonzalez, A. (2007). Development of the vomeronasal amygdala in anuran amphibians: hodological, neurochemical, and gene expression characterization. J. Comp. Neurol. 503, 815-831.

Moreno, N., Morona, R., Lopez, J. M., Munoz, M., and Gonzalez, A. (2005). Lateral and medial amygdala of anuran amphibians and their relation to olfactory and vomeronasal information. Brain Res. Bull. 66, 332-336.

Mueller, T., and Wullimann, M. F. (2009). An evolutionary interpretation of teleostean forebrain anatomy. Brain Behav. Evol. 74, 30-42.

Murakami, T., Morita, Y., and Ito, H. (1983). Extrinsic and intrinsic fiber connections of the telencephalon in a teleost, Sebastiscus marmoratus. J. Comp. Neurol. 216, 115-131.

Nakajima, T., Tanioka, Y., and Taniguchi, K. (2003). Distribution of protein gene product 9.5-immunopositive and NADPH-diaphorase-positive neurons in the common marmoset (Callithrix jacchus) accessory olfactory bulb. J. Vet. Med. Sci. 65, 1307-1311.

Nef, S., Allaman, I., Fiumelli, H., De Castro, E., and Nef,P.(1996). Olfaction in birds: differential embryonic expression of nine putative odorant receptor genes in the avian olfactory system. Mech. Dev. 55, 65-77.

Niimura, Y., and Nei, M. (2003). Evolution of olfactory receptor genes in the human genome. PNAS 100 12235-12240.

Northcutt, R. G., and Puzdrowski, R. L. (1988). Projections of the olfactory bulb and nervus terminalis in the silver lamprey. Brain Behav. Evol. 32, 96-107.

Northcutt, R. G., and Royce, G. J. (1975). Olfactory bulb projections in the bullfrog Rana catesbeiana.J. Morphol. 145 , 251-267.

Perez-Costas, E., Melendez-Ferro, M., Perez-Garcia, C. G., Caruncho, H. J., and Rodicio, M. C. (2004). Reelin immunoreactivity in the adult sea lamprey brain. J. Chem. Neuroanat. 27, 7-21.

Petko, M., and Santa, A. (1992) Distribution of calcitonin generelated peptide immunoreactivity in the central nervous system of the frog, Rana esculenta. Cell Tissue Res. 269, 525-534.

Pfister, P., Randall, J., Montoya-Burgos, J. I., and Rodriguez, I. (2007). Divergent evolution among teleost V1r receptor genes. PLoS One 2, e379. doi: 10.1371/ journal.pone.0000379

Polenova, O. A., and Vesselkin, N. P. (1993). Olfactory and nonolfactory projections in the river lamprey (Lampetra fluviatilis) telencephalon. J. Hirnforsch. 34, 261-279.

Pombal,M.A., de Arriba, M.C., Sampedro, C., Alvarez, R., and Megias, M. (2002). Immunocytochemical localization of calretinin in the olfactory system of the adult lamprey, Lampetrafluviatilis. Brain Res. Bull. 57, 281-283.

Price, J. L. (1973). An autoradiographic study of complementary laminar patterns of termination of afferent fibers to the olfactory cortex. J. Comp. Neurol. 150, 87-108.

Pro-Sistiaga, P., Mohedano-Moriano, A. Ubeda-Banon, I., Del Mar ArroyoJimenez,M., Marcos, P.,Artacho-Perula E., Crespo, C., Insausti, R., and MartinezMarcos, A. (2007). Convergence of olfactory and vomeronasal projections in the rat basal telencephalon. J. Comp. Neurol. 504, 346-362.

Raisman, G. (1972). An experimenta study of the projection of the amygdala to the accessory olfactory bulb and its relationship to the concept of a dual olfactory system. Exp. Brain Res. 14, 395-408.

Reiner, A., and Karten, H. J. (1985) Comparison of olfactory bulb projections in pigeons and turtles. Brain Behav. Evol. 27, 11-27.

Ren, X., Chang, S., Laframboise, A., Green, W., Dubuc, R., and Zielinski,
B. (2009). Projections from the accessory olfactory organ into the medial region of the olfactory bulb in the sea lamprey (Petromyzon marinus): a novel vertebrate sensory structure? J. Comp. Neurol. 516, 105-116.

Rieke, G. K., and Wenzel, B. M. (1978). Forebrain projections of the pigeon olfactory bulb. J. Morphol. 158, 41-55.

Rodriguez,I.,Feinstein, P., and Mombaerts, P. (1999). Variable patterns of axonal projections of sensory neurons in the mouse vomeronasal system. Cell 97, 199-208.

Rodriguez, I., Greer, C. A., Mok, M. Y., and Mombaerts, P. (2000). A putative pheromone receptor gene expressed in human olfactory mucosa. Nat. Genet. 26, 18-19.

Rodriguez, I., and Mombaerts, P. (2002). Novel human vomeronasal receptorlike genes reveal species-specific families. Curr. Biol. 12, R409-R411.

Rouquier, S., Taviaux, S., Trask, B. J., Brand-Arpon, V., van den Engh, G., Demaille, J., and Giorgi, D. (1998). Distribution of olfactory receptor genes in the human genome. Nat. Genet. 18, 243-250.

Ryba, N. J., and Tirindelli, R. (1997). A new multigene family of putative pheromone receptors. Neuron 19, 371-379.

Saito, S., Kobayashi, N., and Atoji, Y. (2006). Subdivision of the accessory olfactory bulb in the Japanese common toad, Bufo japonicus, revealed by lectin histochemical analysis. Anat. Embryol. 211, 395-402.

Satou, M. (1990). Synaptic organization, local neuronal circuitry, and functional segregation of the teleost olfactory bulb. Prog. Neurobiol. 34 115-142.

Savic, I., Heden-Blomqvist, E., and Berglund, H. (2009). Pheromone signal transduction in humans: what can be learned from olfactory loss. Hum. Brain Mapp. 30, 3057-3065

Scalia, F. (1972). The projection of the accessory olfactory bulb in the frog. Brain Res. 36, 409-411.

Scalia, F., and Ebbesson, S. O. (1971). The central projections of the olfactory bulb in a teleost (Gymnothorax funebris). Brain Behav. Evol. 4, 376-399.

Scalia, F., Gallousis, G., and Roca, S. (1991a). Differential projections of the main and accessory olfactory bulb in the frog. J. Comp. Neurol. 305 , 443-461.

Scalia, F., Gallousis, G., and Roca, S. (1991b). A note on the organization of the amphibian olfactory bulb. $J$. Comp. Neurol. 305, 435-442.

Scalia, F., and Winans, S. S. (1975). The differential projections of the olfactory bulb and accessory olfactory 
bulb in mammals. J. Comp. Neurol. 161, 31-55.

Schoenfeld, T. A., and Macrides, F. (1984). Topographic organization of connections between the main olfactory bulb and pars externa of the anterior olfactory nucleus in the hamster. $J$. Comp. Neurol. 227, 121-135.

Shammah-Lagnado, S. J., and Negrao, N. (1981). Efferent connections of the olfactory bulb in the opossum (Didelphis marsupialis aurita): a Fink-Heimer study. J. Comp. Neurol. 201, 51-63.

Sharon, D., Glusman, G., Pilpel, Y., Khen, M., Gruetzner, F., Haaf, T., and Lancet, D. (1999). Primate evolution of an olfactory receptor cluster: diversification by gene conversion and recent emergence of pseudogenes. Genomics 61, 24-36.

Shepherd, G. M. (1972). Synaptic organization of the mammalian olfactory bulb. Physiol. Rev. 52, 864-917.

Shipley, M. T., and Adamek, G. D. (1984). The connections of the mouse olfactory bulb: a study using orthograde and retrograde transport of wheat germ agglutinin conjugated to horseradish peroxidase. Brain Res. Bull. 12, 669-688.

Singru, P. S., Sakharkar, J. A., and Subhedar, N. (2003). Neuronal nitric oxide synthase in the olfactory system of an adult teleost fish Oreochromis mossambicus. Brain Res. 977, 157-168.

Skeen, L. C., and Hall, W. C. (1977). Efferent projections of the main and the accessory olfactory bulb in the tree shrew (Tupaia glis). J. Comp. Neurol. 172, 1-35.

Slaby, O. (1987). Morphological differences between the structure of the nasal apparatus of the swift (Apusapus L.) and the common "avian typus" during morphogenesis. Morphogenesis of the nasal capsule, the epithelial nasal tube and the organ of Jacobson in sauropsida. XVIII. Folia Morphol. 35, 436-440.

Slotnick, B., Restrepo, D., Schellinck, H., Archbold, G., Price, S., and Lin, W. (2010). Accessory olfactory bulb function is modulated by input from the main olfactory epithelium. Eur. J. Neurosci. 31, 1108-1116.

Smeets, W. J. (1983). The secondary olfactory connections in two chondrichthians, the shark Scyliorhinus canicula and the ray Raja clavata. J. Comp. Neurol. 218, 334-344.

Smeets, W. J. (1988). Distribution of dopamine immunoreactivity in the forebrain and midbrain of the snake Python regius: a study with antibodies against dopamine. J. Comp. Neurol. 271, 115-129.

Smeets, W.J., Hoogland, V.P., and Voorn, P. (1986). The distribution of dopamine immunoreactivity in the forebrain and midbrain of the lizard Gekko gecko: an immunohistochemical study with antibodies against dopamine.J. Comp. Neurol. 253, 46-60.

Smeets, W. J., Jonker, A. J., and Hoogland, P.V. (1987). Distribution of dopamine in the forebrain and midbrain of the red-eared turtle, Pseudemys scripta elegans, reinvestigated using antibodies against dopamine. Brain Behav. Evol. 30, 121-142.

Smeets, W. J., and Steinbusch, H. W. (1990). New insights into the reptilian catecholaminergic systems as revealed by antibodies against the neurotransmitters and their synthetic enzymes. J. Chem. Neuroanat. 3, 25-43.

Smith, T. D., and Bhatnagar, K. P. (2000). The human vomeronasal organ. Part II: prenatal development. J. Anat. 197(Pt 3), 421-436.

Smith, T. D., Buttery, T. A., Bhatnagar, K. P., Burrows, A. M., Mooney, M. P., and Siegel,M.I.(2001).Anatomical position of the vomeronasal organ in postnatal humans. Ann. Anat. 183, 475-479.

Smith, T. D., Siegel, M. I., Burrows, A. M., Mooney, M. P., Burdi, A. R., Fabrizio, P. A., and Clemente, F. R. (1998). Searching for the vomeronasal organ of adult humans: preliminary findings on location, structure, and size. Microsc. Res. Tech. 41, 483-491.

Steiger, S. S., Fidler, A. E., Valcu, M., and Kempenaers, B. (2008). Avian olfactory receptor gene repertoires: evidence for a well-developed sense of smell in birds? Proc. Biol. Sci. 275, 2309-2317.

Steiger, S. S., Kuryshev, V. Y., Stensmyr, M. C., Kempenaers, B., and Mueller, J. C. (2009). A comparison of reptilian and avian olfactory receptor gene repertoires: species-specific expansion of group gamma genes in birds. $B M C$ Genomics 10, 446. doi: 10.1186/14712164-10-446

Stensaas, L. J., Lavker, R. M., Monti-Bloch, L., Grosser, B. I., and Berliner, D. L. (1991). Ultrastructure of the human vomeronasal organ.J. Steroid Biochem. Mol. Biol. 39, 553-560.

Suzuki, N. (1984). Anterograde fluorescent labeling of olfactory receptor neurons by Procion and Lucifer dyes. Brain Res. 311, 181-185.

Switzer, R. C. 3rd, and Johnson, J. I. Jr. (1977). Absence of mitral cells in monolayer in monotremes. Variations in vertebrate olfactory bulbs. Acta Anat. 99, 36-42.

Takigami, S., Mori, Y., Tanioka, Y., and Ichikawa, M. (2004). Morphological evidence for two types of mammalian vomeronasal system. Chem. Senses 29 , 301-310.

Taniguchi, K., Saito, S., and Oikawa, T. (2008). Phylogenic aspects of the amphibian dual olfactory system. $J$. Vet. Med. Sci. 70, 1-9.

Thornhill, R. A. (1967). The ultrastructure of the olfactory epithelium of the lamprey Lampetra fluviatilis.J. Cell Sci. 2, 591-602.

Trotier, D., Eloit, C., Wassef, M., Talmain, G., Bensimon, J. L., Doving, K. B., and Ferrand, J. (2000). The vomeronasal cavity in adult humans. Chem. Senses $25,369-380$.

Turner, B. H., Gupta, K. C., and Mishkin, M. (1978). The locus and cytoarchitecture of the projection areas of the olfactory bulb in Macaca mulatta. J. Comp. Neurol. 177, 381-396.

VanDenbossche, J., Seelye, J. G., and Zielinski, B.S. (1995). The morphology of the olfactory epithelium in larval, juvenile and upstream migrant stages of the sea lamprey, Petromyzon marinus. Brain Behav. Evol. 45, 19-24.

Von Campenhause, H., and Mori, K. (2000). Convergence of segregated pheromonal pathways from the accesory olfactory bulb to the cortex in the mouse. Eur. J. Neurosci. 12, 33-46.

Wang, R. T., and Halpern, M. (1982a) Neurogenesis in the vomeronasal epithelium of adult garter snakes. 1 . Degeneration of bipolar neurons and proliferation of undifferentiated cells following experimental vomeronasal axotomy. Brain Res. 237, 23-39.

Wang, R. T., and Halpern, M. (1982b) Neurogenesis in the vomeronasal epithelium of adult garter snakes. 2. Reconstitution of the bipolar neuron layer following experimental vomeronasal axotomy. Brain Res. 237, 41-59.

Wang, R. T., and Halpern, M. (1988). Neurogenesis in the vomeronasal epithelium of adult garter snakes: 3 . Use of H3-thymidine autoradiography to trace the genesis and migration of bipolar neurons. Am. J. Anat. 183 , 178-185.

Westerman, R. A., and Wilson, J. A. (1968). The fine structure of the olfactory tract in the teleost Carassius carassius L.ZZellforsch Mikrosk Anat. 91, 186-199.

Wilson, J.A., and Westerman, R.A. (1967). The fine structure of the olfactory mucosa and nerver in the teleost Carassius carassius L. Z Zellforsch Mikrosk Anat. 83, 196-206.

Winans, S. S., and Scalia, F. (1970). Amygdaloid nucleus: new afferent input from the vomeronasal organ. Science 170, 330-332.

Witt, M., Georgiewa, B., Knecht, M., and Hummel, T. (2002). On the chemosensory nature of the vomeronasal epithelium in adult humans. Histochem. Cell Biol. 117, 493-509.

Witt, M., and Hummel, T. (2006). Vomeronasal versus olfactory epithelium: is there a cellular basis for human vomeronasal perception? Int. Rev. Cytol. 248, 209-259.

Witt, M., and Wozniak, W. (2006). Structure and function of the vomeronasal organ. Adv. Otorhinolaryngol. 63, 70-83.

Woodley, S. K. (2010). Pheromonal communication in amphibians. J. Comp. Physiol. A. Neuroethol. Sens. Neural Behav. Physiol. 196, 713-727.

Xu, F., Schaefer, M., Kida, I., Schafer, J., Liu, N., Rothman, D. L., Hyder, F., Restrepo, D., and Shepherd, G. M. (2005). Simultaneous activation of mouse main and accessory olfactory bulbs by odors or pheromones. $J$. Comp. Neurol. 489, 491-500.

Young, J. M., Friedman, C., Williams, E. M., Ross, J. A., Tonnes-Priddy, L., and Trask, B. J. (2002). Different evolutionary processes shaped the mouse and human olfactory receptor gene families. Hum. Mol. Genet. $11,535-546$.

Yuen, A. P., Fan, Y. W., Fung, C. F., and Hung, K. N. (2005). Endoscopicassisted cranionasal resection of olfactory neuroblastoma. Head Neck 27, 488-493.

Zaccone, D., Cascio, P. L., Lauriano, R., Pergolizzi, S., Sfacteria, A., and Marino, F. (2010). Occurrence of neuropeptides and tyrosine hydroxylase in the olfactory epithelium of the lesser-spotted catshark (Scyliorhinus canicula Linnaeus, 1758). Acta Histochem doi:10.1016/j.acthis.2010.09.010

Conflict of Interest Statement: The authors declare that the research was conducted in the absence of any commercial or financial relationships that could be construed as a potential conflict of interest.

Received: 29 October 2010; paper pending published: 10 December 2010; accepted: 11 January 2011; published online: 26 January 2011.

Citation: Ubeda-Bañon I, Pro-Sistiaga P, Mohedano-Moriano A, Saiz-Sanchez D, de la Rosa-Prieto C, Gutierrez-Castellanos $N$, Lanuza E, Martinez-Garcia F and Martinez-Marcos A (2011) Cladistic analysis of olfactory and vomeronasal systems. Front. Neuroanat. 5:3. doi: 10.3389/ fnana.2011.00003

Copyright (๑) 2011 Ubeda-Bañon, Pro-Sistiaga, Mohedano-Moriano, Saiz-Sanchez, de la Rosa-Prieto, GutierrezCastellanos, Lanuza, Martinez-Garcia and Martinez-Marcos. This is an open-access article subject to an exclusive license agreement between the authors and Frontiers Media SA, which permits unrestricted use, distribution, and reproduction in any medium, provided the original authors and source are credited. 